\title{
Recent Developments in Gateway Phase Research
}

\author{
Rand A. Greubel
}

Alpine Archaeological Consultants, Inc.

\begin{abstract}
The Gateway tradition was defined by Alan D. Reed in 1997 to describe a class of prehistoric sites in west-central Colorado that had previously only been described in generic terms or as a local variant of well-known cultural traditions such as Ancestral Puebloan or Fremont. Reed and Michael D. Metcalf elaborated upon the new archaeological taxon in the prehistoric context for the Northern Colorado River basin, which was published in 1999. Several studies and research projects conducted since that time have resulted in new datasets that are relevant to many of the research questions and data gaps identified by Reed and Metcalf for the Gateway tradition. A consideration of these data has resulted in new insights into the lifeways of these people and a taxonomic reformulation of the Gateway tradition into the Gateway phase.
\end{abstract}

Keywords: Gateway tradition; Ancestral Puebloan; Anasazi; Fremont culture; Pueblo II period

In the 1999 prehistoric context for the Northern Colorado River basin, Alan Reed and Mike Metcalf summarized what was then known about the Gateway tradition, a Formative-era cultural taxon that Reed had formally defined and named only two years earlier (Reed 1997; Reed and Metcalf 1999). The archaeological unit that Reed christened in 1997 had been the subject of investigation by numerous archaeologists since the 1920s. The lack of consensus regarding Gateway tradition origins and the identity of its progenitors qualifies these sites as somewhat of a genuine archaeological mystery.

Briefly stated, the Gateway tradition as defined by Reed encompasses a group of sites concentrated on the southwestern flank of the Uncompahgre Plateau, within the San Miguel River basin, and in the Paradox Valley, but with possible outliers extending northward over the crest of the Uncompahgre Plateau and into the Escalante Creek drainage, and westward to the La Sal and Moab areas of eastern Utah (figures 1 and 2). The sites are distinguished by the presence of stone masonry architecture, low numbers of Ancestral Puebloan ceramics, small corner- and side-notched arrow points, and small quantities of maize reflecting at least limited horticulture. Beyond this basic list, some sites, such as Paradox I (5MN191), also exhibit pithouses, whereas others are associated with rock art that in many respects appears to be Puebloan, though with possible Fremont influences in some cases. Known architectural Gateway sites are listed in table 1 and known or suspected non-architectural Gateway sites are listed in table 2. These lists are not exhaustive but rather represent sites reported in the literature or easily identified in the Colorado Office of Archaeology and Historic Preservation's (OAHP) database.

The goals of this article are to summarize recent developments in Gateway tradition research, to re-examine the research questions and data gaps identified by Reed and Metcalf in the 1999 context and upon which the recent data have shed new light, to address the more controversial aspects of the Gateway tradition construct in the light of the 


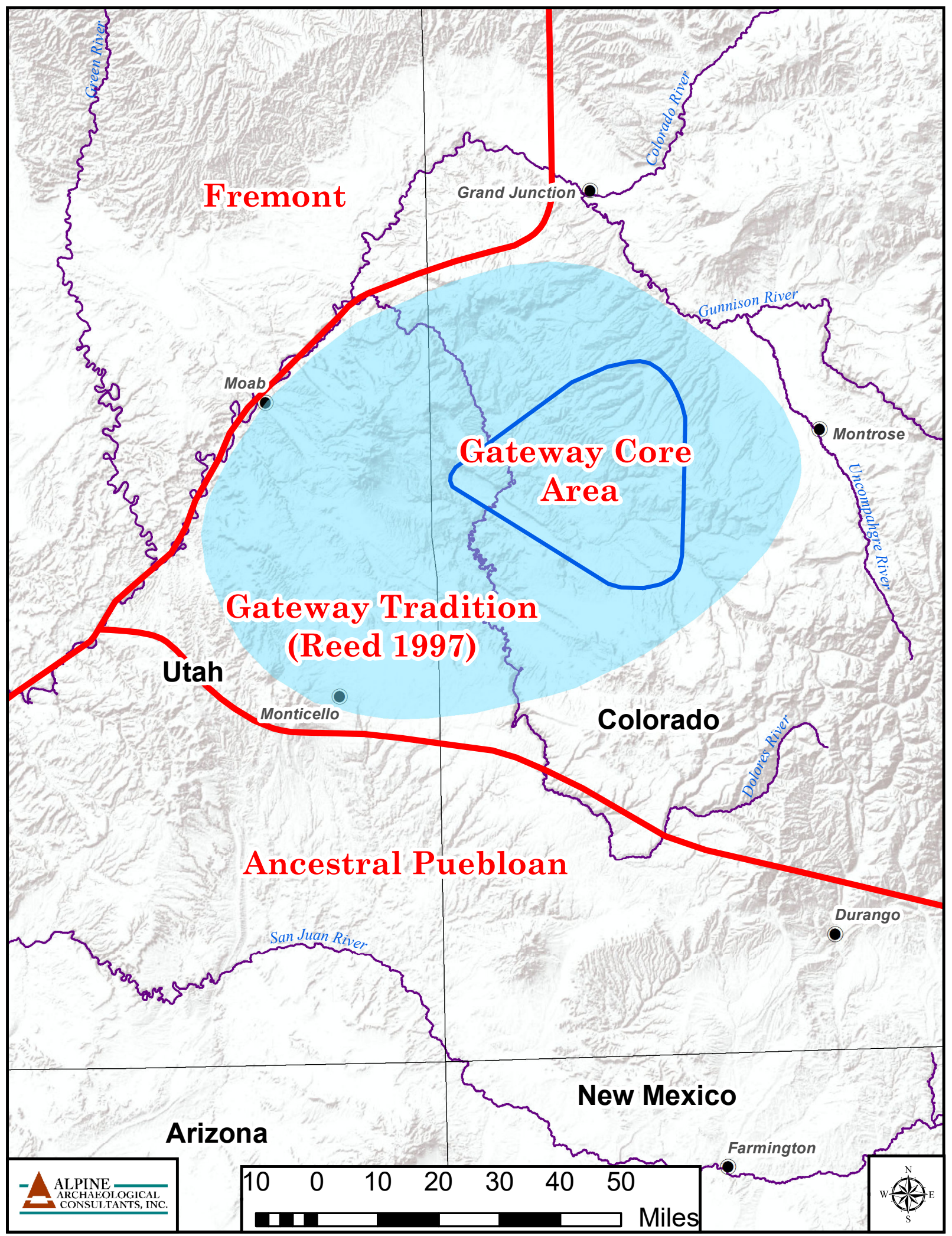

Figure 1. Map showing the geographic extent of Ancestral Puebloan, Fremont, and Gateway cultures. The hypothetical maximum extent of Gateway sites is based on Reed (1997:Figure 1). 
new research, and to present new interpretations and identify new research questions and data gaps.

\section{Early Research}

Much early archaeological work in Montrose and San Miguel counties focused on sites that would later come to be included in the Gateway tradition construct, mainly because these sites were highly visible and appeared to have some sort of connection to the Southwest. Jean Allard Jeançon and Frank H. H. Roberts of the State Historical Society of Colorado (now known as History Colorado) conducted the first professional investigations in the region in 1924, mapping sites in the Paradox Valley and excavating several structures at 5MN191 (also known as Paradox I or Wray Mounds) (Jeançon 1924; McMahon 1997). George and Edna Woodbury, also representing the State Historical Society, likewise focused on the Paradox Valley during their 1931 expedition; they mapped the sites in the valley and excavated several additional structures at Paradox I (Woodbury and Woodbury 1932). Jeançon and the Woodburys considered these sites to be peripheral, northern expressions of what was then called the Anasazi tradition.

In the late 1930s and early 1940s, Betty and Harold Huscher documented and excavated or tested several sites with stone structures in the region, proposing that although some of the rectangular structures may represent an Anasazi presence, the circular to ovate structures reflect early Athapaskan occupations (Huscher and Huscher 1943; Huscher and Huscher 1939). C.T. Hurst of Western State College began a series of excavations of structural sites in Montrose County in the 1940s that included Cottonwood Pueblo, Hill Pueblo, and Tabeguache Pueblo (Hurst 1946, 1948a, 1948b). Like earlier investigators, Hurst considered these structural sites to be northern peripheral examples of Anasazi occupation (Hurst 1946:10, 1948a).

The next series of professional excavations began in 1970 with work by Larry Leach, then affiliated with Colorado College, at a different area of the Paradox I site than those investigated by Jeançon and Roberts and the Woodburys (Leach 1972). In 1973, Jiri Vondracek and his students from Metropolitan State College in Denver (MSC, now known as Metropolitan State University of
Denver), conducted additional, though limited, excavations at Paradox I. Following this, Vondracek conducted extensive excavations at several sites at the Weimer Ranch (formerly the Hill Ranch), including Cottonwood Pueblo (5MN654), as an MSC field school from 1974 to 1977 . None of the excavations conducted by Leach or Vondracek were ever formally reported, although Leach briefly summarized his work in a National Science Foundation grant proposal (Leach 1972). Leach's 1970 investigations were also briefly described in an M.A. thesis and article by Jan Kasper (1977), whereas the MSC excavations were described by Cathy Crane (1977) in an M.A. thesis and an article (Crane 1978).

Few additional field or analytical projects involving Gateway sites or assemblages have been conducted since the work described previously. However, projects from the late 1970s to the present that generated relevant primary data through survey (intensive or reconnaissance), testing, or analysis of artifacts and other materials include Toll (1977), McMahon and Bedingfield (2001), Greubel and others (2006), Reed and Emslie (2008), Bedingfield (2009), and Martin and Shelton (2015). Some primary data regarding Gateway sites can also be gleaned from inventories reported in regional gray literature. Important synthetic articles, papers, reports, theses, comments, or overviews related to the Gateway tradition include, in chronological order, Schroeder (1964), Gleichman and Legard (1977), Gleichman and others (1982), Reed (1997), McMahon (1997), Reed and Metcalf (1999), McMahon (2000), McMahon and Bedingfield (2001), McMahon (2004), Reed (2005), Greubel and others (2006), Greubel (2006), Andrews (2006), L.S. Reed (2006, 2007), Andrews and Greubel (2007), McMahon (2007), Reed (2007), Varien (2007), Reed and Emslie (2008), Bedingfield (2009), and Martin and Shelton (2015).

\section{New Research into Gateway Sites}

In the prehistoric context document for the Northern Colorado River basin, Reed and Metcalf (1999) presented a number of critical research questions and data gaps for the Gateway tradition. Eighteen years later, many have either not been resolved or have been only incompletely answered. Significant 


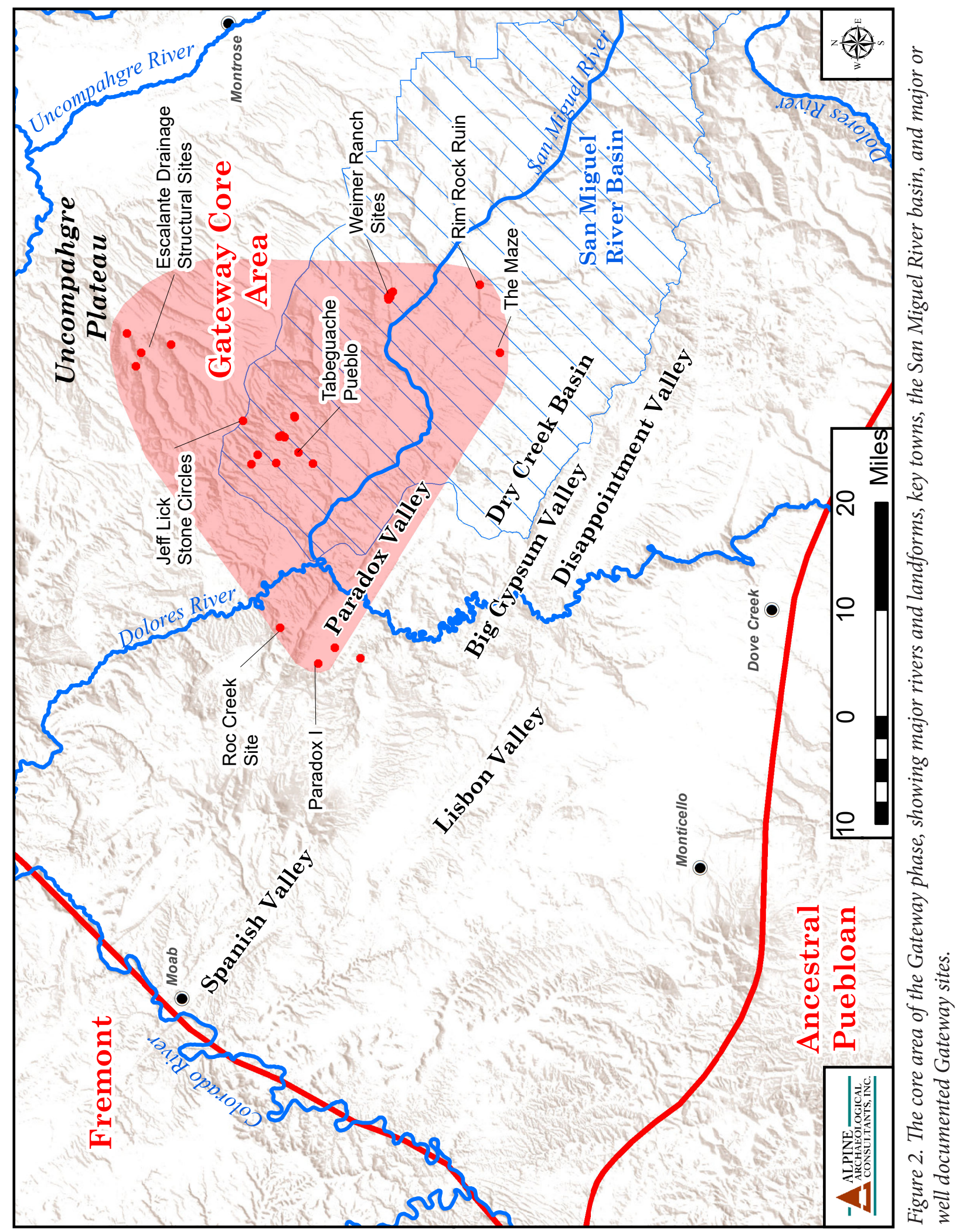


Greubel

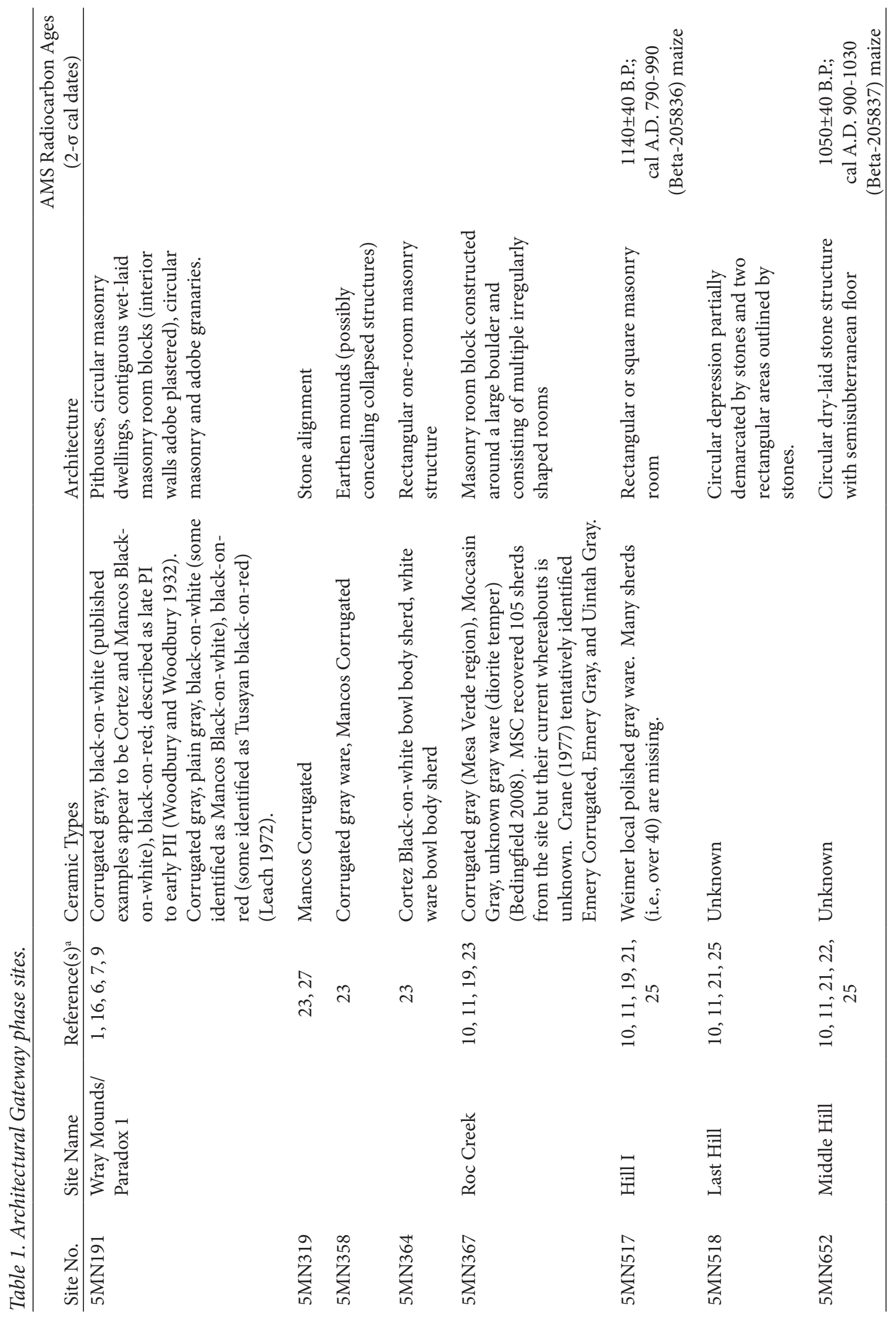




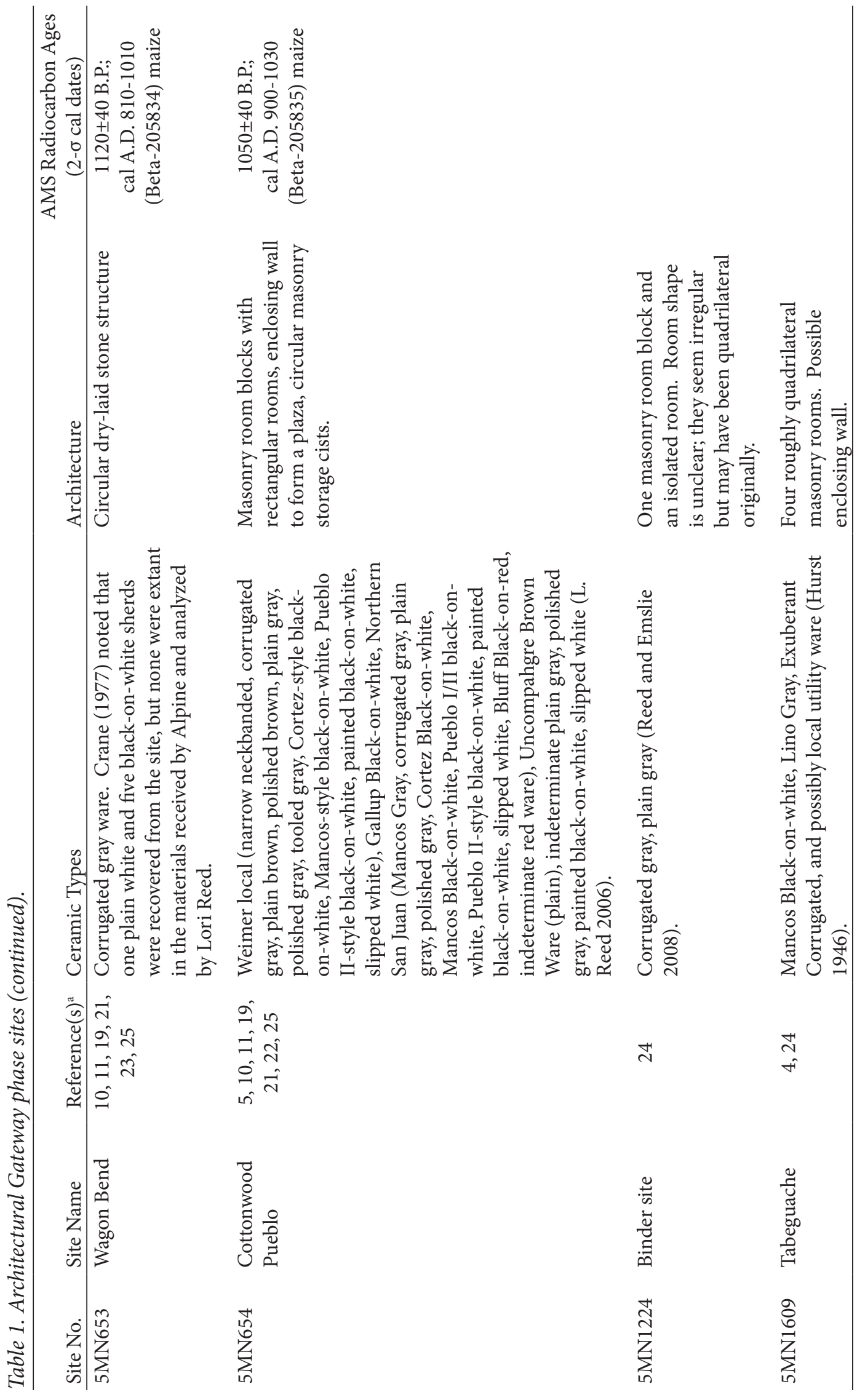




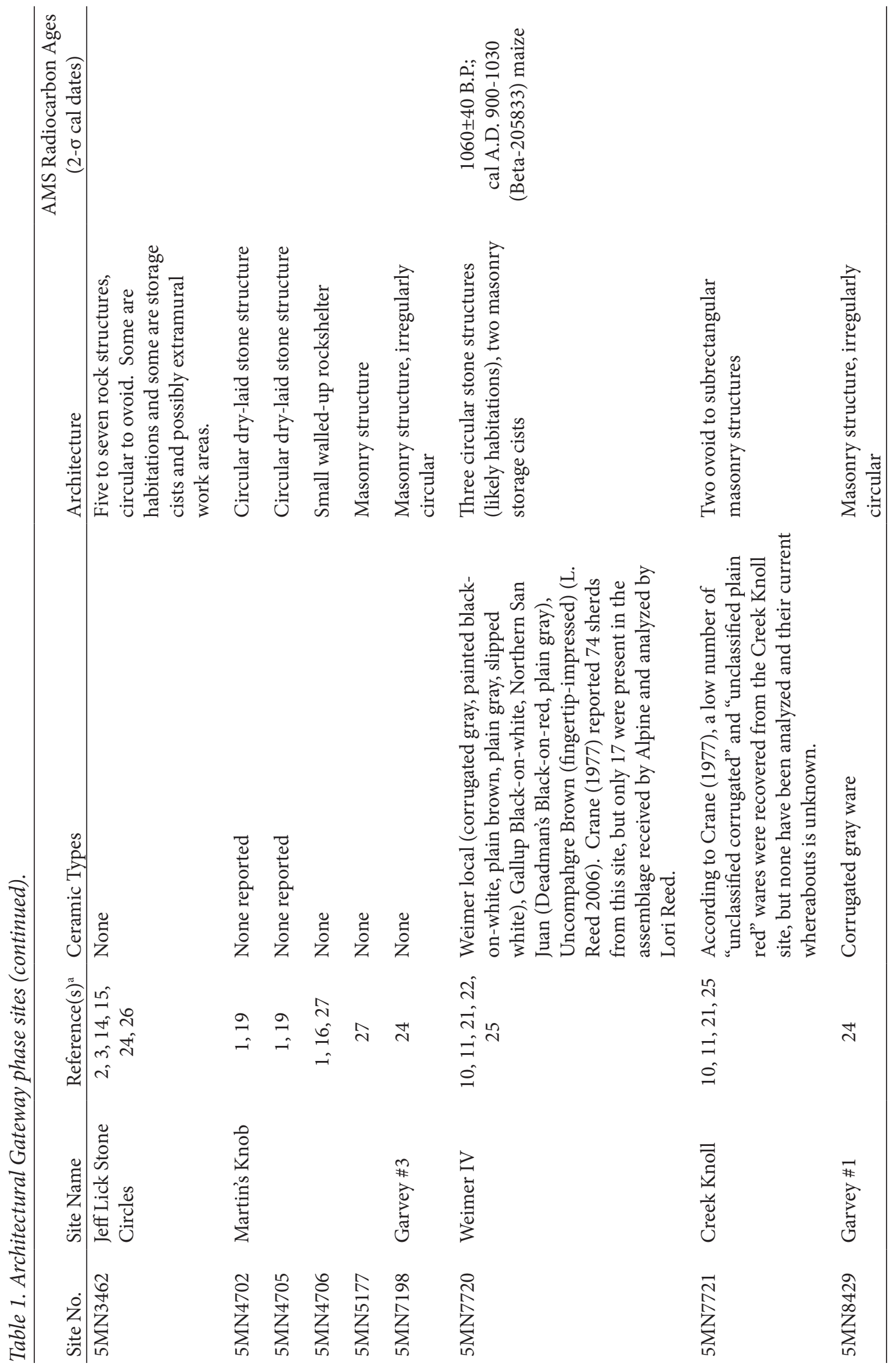


Recent Developments in Gateway Phase Research

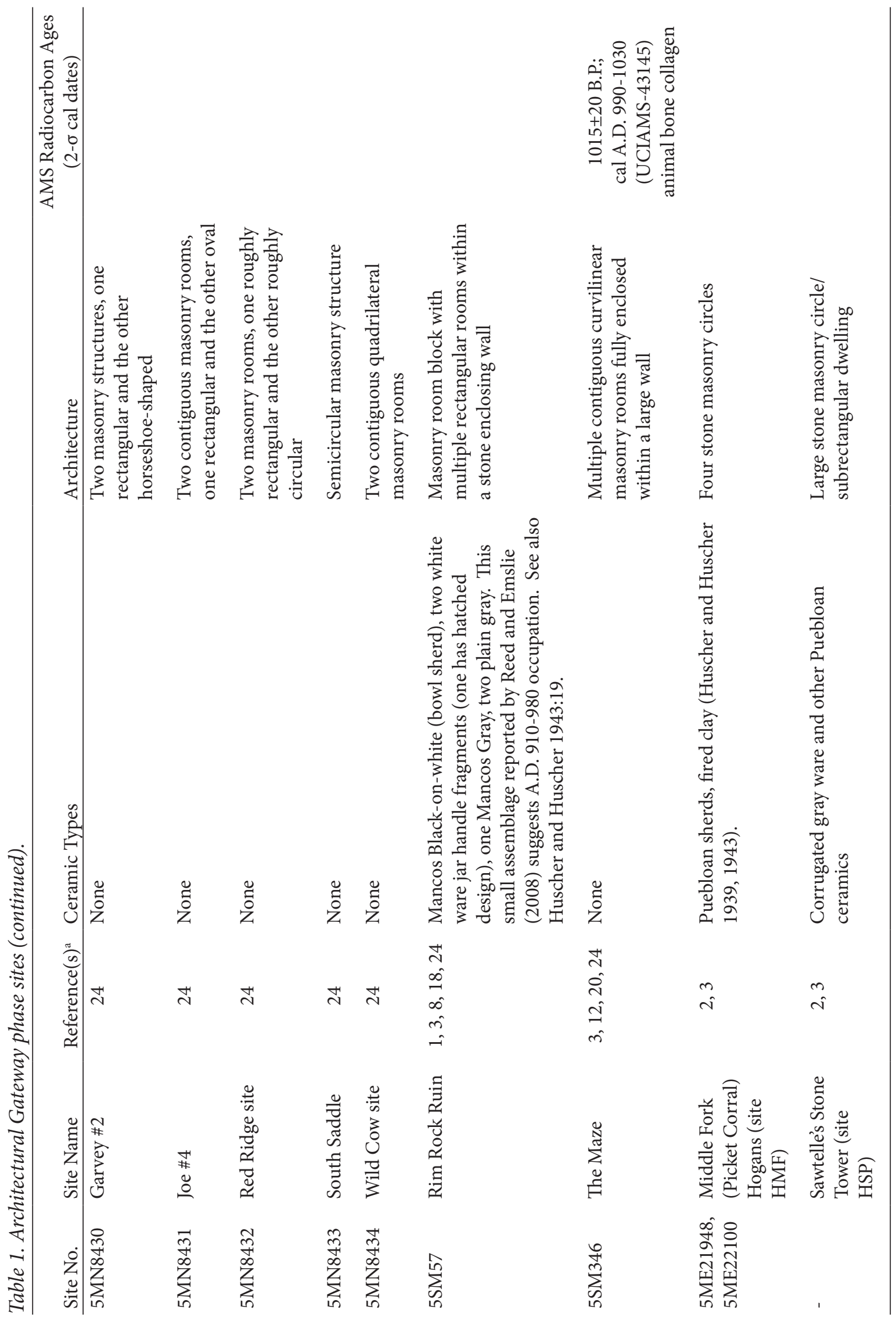




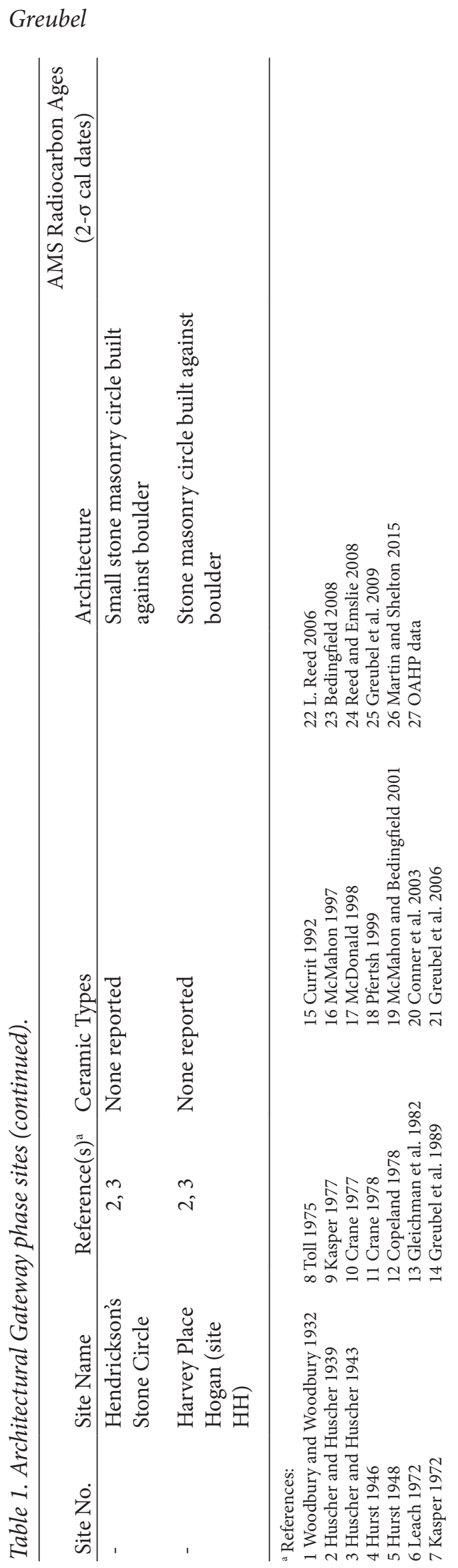

Recent Developments in Gateway Phase Research 
progress, however, has been made in tentatively answering several of the questions and rectifying the associated data gaps, relying on research conducted since the context document was written. This research has also generated new questions. The most significant new data or analyses relevant to a number of key Gateway tradition research issues were obtained from three studies involving existing collections and two projects involving new fieldwork, all conducted over the past 12 years, which are summarized in the following sections.

Analysis of MSC's Weimer Ranch Materials

In 2005, Alpine Archaeological Consultants, Inc. (Alpine) analyzed the artifacts and other materials excavated by MSC from nine sites clustered along Cottonwood Creek at the Weimer Ranch in western Montrose County. The work was funded by a grant from History Colorado's State Historical Fund. The results of the study are presented in a technical report (Greubel et al. 2006), and summarized in an article published in Colorado Archaeology (Greubel et al. 2009). MSC's excavations were primarily focused on structure interiors. A diverse collection of nearly 10,000 artifacts was analyzed, including diagnostic projectile points and an assemblage of 238 ceramic sherds. Substantial faunal and macrofloral assemblages, the latter including maize remains, were also studied.

Ten new radiocarbon dates were obtained (table 3 ), including five accelerator mass spectrometry (AMS) dates on maize (Greubel et al. 2006). The maize dates encompass similar calendrical age ranges, with the exception of a specimen from Hill I, which produced a slightly earlier date; their combined two-sigma calibrated age ranges span the period A.D. 790-1030. The maize dates were tested for contemporaneity and found to be statistically equivalent $(\alpha=0.05)$ at the 95 percent confidence level $(\mathrm{t}=4.58)$. Their pooled mean radiocarbon age is calculated at $1084 \pm 18{ }^{14} \mathrm{C}$ yr B.P., which yields calibrated calendrical date ranges of A.D. 900-920 and 940-1010, with associated probabilities of 0.31 and 0.69 , respectively (Greubel et al. 2006). Pooling these statistically contemporaneous dates to derive a mean radiocarbon age is appropriate because the dates are on similar materials and were processed by the same laboratory (Shott 1992:212). A more detailed discussion of the radiocarbon dating and comparisons between the AMS dates and the ceramic chronology is presented in Greubel and others (2009). Aside from substantially refining the chronology of the Weimer Ranch sites from Crane's $(1977,1978)$ original estimates, the maize dates suggest the possibility that five of the principal Weimer Ranch sites may all have been occupied contemporaneously.

The project included a ground-breaking analysis of the ceramic assemblage by a respected Southwestern ceramic specialist, Lori Reed, that appears to have established the likelihood of the existence of a local ceramic tradition. A limited number of sherds were also subjected to instrumental neutron activation analysis (INAA).

Social Organization at the Weimer Ranch Sites

This study, which relied on the data produced through Alpine's analysis of the Weimer Ranch collection, examined aspects of site structure, community layout, and assemblage composition at the Weimer Ranch sites to formulate hypotheses about Gateway tradition social organization (Greubel 2006). The study was underpinned by the assumption, based on the newly obtained AMS dates discussed previously, that most of the sites within the Weimer Ranch locale were contemporaneous and collectively represented a community as defined by Varien (1999). Given their contemporaneity, the study posited social and economic explanations for the striking differences in architecture, site layout, and setting between the sites, as well as both intra- and inter-site assemblage composition, relying on spatial relationships and analogs derived from ethnohistoric studies of Puebloan social organization. Integrative spaces and evidence of economic cooperation in the community were identified that include a possible plaza at Cottonwood Pueblo, communal work areas, a possible central community house at Weimer IV (5MN7720), and communal storage features at the two largest sites. Heterarchical as opposed to hierarchical social arrangements were proposed to explain some of the differences between the sites.

The study also hypothesized that some of the diversity among sites and assemblages might be related to ethnic or cultural differences, with 
Table 2. Non-architectural Gateway phase sites; none have been radiocarbon dated.

\begin{tabular}{|c|c|c|c|c|}
\hline Site No. & Site Name & Reference $(\mathrm{s})^{\mathrm{a}}$ & Ceramic Types & Notes \\
\hline 5MN75 & & 27 & & $\begin{array}{l}\text { OAHP data list cultural affiliation } \\
\text { as "Pueblo II; Pueblo III," but does } \\
\text { not mention the evidence for this } \\
\text { assignation. }\end{array}$ \\
\hline $5 \mathrm{MN} 100$ & & 23 & Corrugated gray ware & \\
\hline $5 \mathrm{MN} 141$ & & 23 & $\begin{array}{l}\text { Unknown micaceous, Jeddito } \\
\text { Black-on-yellow bowl sherd }\end{array}$ & \\
\hline $5 \mathrm{MN} 154$ & & 23 & & $\begin{array}{l}\text { Mentioned in Bedingfield (2008) as a } \\
\text { ceramic site. Compass and the BLM- } \\
\text { UFO database do not list ceramics. }\end{array}$ \\
\hline $5 \mathrm{MN} 159$ & & 23 & $\begin{array}{l}\text { Mancos Black-on-white } \\
\text { (dipper), plain gray }\end{array}$ & \\
\hline 5MN345 & & 23 & Unknown micaceous & \\
\hline $5 \mathrm{MN} 359$ & & 23 & Corrugated gray ware & \\
\hline $5 \mathrm{MN} 362$ & & 23 & Corrugated gray ware & \\
\hline $5 \mathrm{MN} 368$ & Battleship & $10,11,21,25$ & None known & $\begin{array}{l}\text { Rubble suggesting structures is } \\
\text { present but undocumented }\end{array}$ \\
\hline $5 \mathrm{MN} 665$ & No. 90 & $\begin{array}{c}10,11,21,22 \\
25\end{array}$ & Unknown & Weimer Ranch site \\
\hline $5 \mathrm{MN} 776$ & & 23 & Corrugated gray ware & \\
\hline $5 \mathrm{MN} 777$ & & 23 & $\begin{array}{l}\text { Piedra Black-on-white, other } \\
\text { white ware }\end{array}$ & \\
\hline $5 \mathrm{MN} 805$ & & 23 & $\begin{array}{l}\text { McElmo Black-on-white } \\
\text { (dipper sherd) }\end{array}$ & \\
\hline $5 \mathrm{MN} 830$ & & 27 & & $\begin{array}{l}\text { OAHP data list cultural affiliation } \\
\text { as "Pueblo II; Pueblo III," but does } \\
\text { not mention the evidence for this } \\
\text { assignation. }\end{array}$ \\
\hline $5 \mathrm{MN} 925$ & & 27 & Mancos Black-on-white & \\
\hline $5 \mathrm{MN} 1834$ & & 27 & Corrugated gray ware & OAHP data lists as PII \\
\hline 5MN5238 & & 27 & None & $\begin{array}{l}\text { OAHP data lists Gateway affiliation } \\
\text { based on a corn cob }\end{array}$ \\
\hline $5 \mathrm{MN} 6889$ & & 27 & Corrugated gray ware & \\
\hline $5 \mathrm{SM} 47$ & & 8 & $\begin{array}{l}\text { Mancos Corrugated rim sherd, } \\
\text { corrugated gray ware, Mesa } \\
\text { Verde gray ware with sand } \\
\text { temper }\end{array}$ & \\
\hline 5SM49 & & 8 & Mesa Verde white ware & \\
\hline 5SM92 & & 23 & $\begin{array}{l}\text { Chapin Gray, Mancos } \\
\text { Corrugated }\end{array}$ & \\
\hline 5SM186 & & 23 & Moccasin Gray, plain gray & \\
\hline 5SM363 & & 13,27 & Corrugated gray ware & Rockshelter \\
\hline
\end{tabular}


Table 2. Non-architectural Gateway phase sites (continued).

\begin{tabular}{|c|c|c|c|c|}
\hline Site No. & Site Name & Reference $(s)^{\mathrm{a}}$ & Ceramic Types & Notes \\
\hline 5SM2578 & $\begin{array}{l}\text { Fallen } \\
\text { Deer }\end{array}$ & 17 & $\begin{array}{l}\text { Mancos Gray, Mancos } \\
\text { Corrugated, painted } \\
\text { white ware, and plain and } \\
\text { corrugated gray wares }\end{array}$ & \\
\hline 5SM3965 & & 27 & & $\begin{array}{l}\text { OAHP data lists Late Prehistoric and } \\
\text { Ancestral Puebloan projectile points } \\
\text { and Ancestral Puebloan ceramics. }\end{array}$ \\
\hline $5 \mathrm{SM} 4124$ & & 27 & Plain ware rim sherd & $\begin{array}{l}\text { Recorders type the sherd as Ancestral } \\
\text { Puebloan }\end{array}$ \\
\hline \multicolumn{5}{|l|}{ a References: } \\
\hline \multicolumn{2}{|c|}{1 Woodbury and Woodbury 1932} & \multicolumn{2}{|c|}{10 Crane 1977} & 19 McMahon and Bedingfield 2001 \\
\hline \multicolumn{2}{|c|}{2 Huscher and Huscher 1939} & \multicolumn{2}{|c|}{11 Crane 1978} & 20 Conner et al. 2003 \\
\hline \multirow{2}{*}{\multicolumn{2}{|c|}{$\begin{array}{l}3 \text { Huscher and Huscher } 1943 \\
4 \text { Hurst } 1946\end{array}$}} & \multicolumn{2}{|c|}{12 Copeland 1978} & 21 Greubel et al. 2006 \\
\hline & & \multicolumn{2}{|c|}{13 Gleichman et al. 1982} & 22 L. Reed 2006 \\
\hline \multicolumn{2}{|l|}{5 Hurst 1948} & \multicolumn{2}{|c|}{14 Greubel et al. 1989} & 23 Bedingfield 2008 \\
\hline \multirow{2}{*}{\multicolumn{2}{|c|}{$\begin{array}{l}6 \text { Leach } 1972 \\
7 \text { Kasper } 1972\end{array}$}} & \multicolumn{2}{|c|}{15 Currit 1992} & 24 Reed and Emslie 2008 \\
\hline & & \multicolumn{2}{|c|}{16 McMahon 1997} & 25 Greubel et al. 2009 \\
\hline \multicolumn{2}{|l|}{8 Toll 1975} & \multirow{2}{*}{\multicolumn{2}{|c|}{$\begin{array}{l}17 \text { McDonald } 1998 \\
18 \text { Pfertsh } 1999\end{array}$}} & 26 Martin and Shelton 2015 \\
\hline \multicolumn{2}{|l|}{9 Kasper 1977} & & & 27 OAHP data \\
\hline
\end{tabular}

Cottonwood Pueblo and its somewhat more normative Puebloan architecture and assemblages representing the habitations of immigrant Puebloan settlers, and the smaller sites with circular structures representing the dwellings of indigenouslocal groups attached to the community, similar to symbiotic relationships documented ethnographically among farmers and foragers in many parts of the world.

Archaeological Assessment of Twelve Gateway Tradition Sites

In 2007, Alan Reed of Alpine and Steven Emslie of the University of North Carolina, Wilmington visited, documented, and tested 12 structural Gateway tradition sites in San Miguel and western Montrose counties. The project, funded with a grant from History Colorado's State Historical Fund, was regarded as a first step in identifying potential sites for excavation, through a process of "ranking of those sites in terms of scientific research potential" (Reed and Emslie 2008:1). As a result of the project, the sites were mapped, photographed, formally recorded on Colorado Cultural Resource Survey forms, evaluated for eligibility to the National Register of Historic Places (NRHP), and tested. Three sites-Garvey \#1 (5MN8429), Garvey \#2 (5MN8430), and the Binder site (5MN1224) - were identified as the best candidates for future excavation based on their potential to yield data relevant to important research questions about the Gateway tradition. The project yielded 14 new AMS dates, though most are of limited utility because of probable old wood and cross-section effects (Reed and Metcalf 1999; Smiley 1985). However, an age of $1015 \pm 20{ }^{14} \mathrm{C}$ yr B.P., calibrated at two-sigma to A.D. 990-1030, was obtained on bone collagen from site 5SM346 (the Maze), and likely accurately reflects the true period of occupation.

Ceramic Study Utilizing Instrumental Neutron Activation Analysis

For his M.A. thesis from the University of Colorado at Denver, Kenneth Bedingfield examined pottery from 16 Formative-era (Late Prehistoric) sites, most of which lack architecture, in areas of Montrose and San Miguel counties that Reed (1997) included within the geographic range of the Gateway tradition. A total of 221 sherds representing 26 vessels was subjected to typological classification and technological characterization by the author, and compositional analyses using INAA were conducted at the University of Missouri Research Reactor Laboratory (MURR) (Bedingfield 2009). In addition to the ceramic study, clay samples were 
Table 3. Radiocarbon dates obtained during Alpine's analysis of the Weimer Ranch materials (Greubel et al. 2006).

\begin{tabular}{|c|c|c|c|c|c|c|c|c|}
\hline $\begin{array}{l}\text { Laboratory } \\
\text { No. }\end{array}$ & $\begin{array}{l}\text { Sample } \\
\text { No. }\end{array}$ & Site & Context & Material Dated & ${ }^{14} \mathrm{C}$ yr B.P. & S.D. & $\delta^{13} \mathrm{C}$ & $\begin{array}{c}\text { Cal Dates } \\
(2-\sigma)\end{array}$ \\
\hline Beta-205227 & Rim-1 & $\begin{array}{l}\text { Cottonwood } \\
\text { Pueblo }\end{array}$ & Hearth & $\begin{array}{l}\text { Wood charcoal } \\
\text { (radiometric) }\end{array}$ & 850 & 50 & -21.2 & A.D. $1040-1270$ \\
\hline Beta-205835 & R2-1 & $\begin{array}{l}\text { Cottonwood } \\
\text { Pueblo }\end{array}$ & Unknown & Maize (AMS) & 1050 & 40 & -9.9 & A.D. $900-1030$ \\
\hline Beta-205224 & WR2-1 & $\begin{array}{l}\text { Cottonwood } \\
\text { Pueblo }\end{array}$ & "Floor" & $\begin{array}{l}\text { Wood charcoal } \\
\text { (radiometric) }\end{array}$ & 1320 & 90 & -22.2 & A.D. $570-900$ \\
\hline Beta-205836 & $\mathrm{H}-1$ & Hill I & "Unit 1" & Maize (AMS) & 1140 & 40 & -11.3 & A.D. $790-990$ \\
\hline Beta-205834 & WB-1 & Wagon Bend & $\begin{array}{l}\text { "Unit } 1 \\
\text { below the } \\
\text { rock" }\end{array}$ & Maize (AMS) & 1120 & 40 & -11.6 & A.D. $810-1010$ \\
\hline Beta-205837 & MH-1 & Middle Hill & $\begin{array}{l}\text { "Unit 1, soil } \\
\text { beneath } \\
\text { rocks" }\end{array}$ & Maize (AMS) & 1050 & 40 & -10.5 & A.D. $900-1030$ \\
\hline Beta-205225 & W4-1 & Weimer IV & $\begin{array}{l}\text { "Unit } 1 \\
\text { surface" }\end{array}$ & $\begin{array}{l}\text { Wood charcoal } \\
\text { (radiometric) }\end{array}$ & 1980 & 60 & -23.5 & $\begin{array}{l}110 \text { B.C.- } \\
\text { A.D. } 130\end{array}$ \\
\hline Beta-205226 & W4-2 & Weimer IV & $\begin{array}{l}\text { "Unit } 2 \text { - } \\
\text { fire pit" }\end{array}$ & $\begin{array}{l}\text { Wood charcoal } \\
\text { (radiometric) }\end{array}$ & 1290 & 80 & -21.5 & A.D. $620-900$ \\
\hline Beta-205833 & W4-3 & Weimer IV & "Unit 3" & Maize (AMS) & 1060 & 40 & -11.6 & A.D. $900-1030$ \\
\hline Beta-205229 & CK-1 & Creek Knoll & Unknown & $\begin{array}{c}\text { Probable } \\
\text { wood charcoal } \\
\text { (AMS) }\end{array}$ & 1260 & 40 & -20.9 & A.D. $670-880$ \\
\hline
\end{tabular}

collected from 12 local sources and subjected to compositional analyses; this provided a dataset against which the composition of the sherds could be compared to test for the possibility of local production.

Based on temper types and refired clay colors, most of the examined sherds appeared to have been manufactured in the Mesa Verde region (Bedingfield 2009:163). Furthermore, many sherds exhibited crushed diorite temper, which is a characteristic of the Dolores Manufacturing tract as defined during the Dolores Archaeological project (Bedingfield 2009:163). A micaceous sherd of unknown cultural affiliation and a sherd of Jeddito Black-on-Yellow were also identified in the assemblage. The 20 sherds to which date ranges could be assigned reflect Pueblo I period pottery types (30 percent), Pueblo II period types (50 percent), Pueblo III period types (5 percent), and types that likely postdate A.D. 1300 (15 percent). The results of the INAA analysis indicate that the sherds are representative of "multiple sources of origin" (Bedingfield 2009:179). Based on comparison against known compositional groups in the MURR database, nearly 35 percent of the analyzed specimens appear to have been manufactured in areas south of the study area that might be described as Ancestral Puebloan homelands. Intriguingly, membership in known compositional groups could not be demonstrated for 65 percent of the pottery in this study. Bedingfield suggested that these data may be "indicative of involvement in a redistributive exchange network for the study area as a whole" (Bedingfield 2009:188). No correspondence could be established between the clay samples and any of the ceramics in the study. He concluded that most of the pottery in his study appeared to represent Ancestral Puebloan manufacture and probably originated south of the study area, although he conceded that at least some of the ceramics associated with previously unknown compositional groups might represent local manufacture. Bedingfield further concluded, based on multiple lines of evidence, that no Fremont pottery types were represented in the assemblage. 
Site Reevaluation and Test Excavations at the Jeff Lick Stone Circles (5MN3462)

In the summer of 2014, the Dominquez Archaeological Research Group, Inc. (DARG) conducted limited excavations at the Jeff Lick Stone Circles site, a high-elevation structural site near the crest of the Uncompahgre Plateau (Martin and Shelton 2015). The site, at an elevation of $9600 \mathrm{ft}$, was first documented and partially excavated by the Huschers in the early 1940s (Huscher and Huscher 1943). It was relocated and recorded by a U.S. Forest Service archaeological crew in 1989 (Currit 1992; Greubel et al. 1989), and tested by Reed and Emslie in 2007 (Reed and Emslie 2008) as part of Alpine's Gateway tradition site assessment project.

Hypothesizing that the site may have "functioned as a temporary encampment established for the purpose of seasonal meat procurement," DARG focused primarily on the excavation of Structure 4-A, an apparent storage feature between the habitation structures. The results of these investigations confirmed that Structure 4-A is a storage unit, essentially comprising a large stone-lined cist. After the pit was excavated, DARG recorded temperature readings at the interior base, as well as on the ground surface outside the feature. They found that the temperature inside the storage feature was in the range of 40-42 degrees F, 20 to 25 degrees cooler than the shaded ground surface outside the feature. Protein residue testing of stones from near the base of Structure 4-A yielded a positive reaction to bovine antisera, a result that indicates the presence of blood from animals within the Bovidae and Antilocapridae families, suggesting bison, bighorn sheep, or pronghorn. Of these, Martin and Shelton (2015:33) consider bighorn sheep to be the most likely candidate for the game that was processed and stored at the site.

DARG concluded that the site served as a summer-through-fall habitation at which faunal resources that were plentiful in the high country were processed and stockpiled for later transport and consumption at lower elevation habitation sites. They also speculate that the site may have been a "way station" for travelers between the southwestern and northeastern sides of the Uncompahgre Plateau. This idea has considerable merit and will be touched upon again later in this article.

\section{Research Questions, Data Gaps, and New Insights}

The following section briefly summarizes the research questions and associated data gaps identified by Reed and Metcalf (1999), for which relevant new data have become available during the past 18 years. The section is organized by research domain. Each summary is followed by a discussion of the new data and interpretations derived from the research, which is described in the preceding section, conducted since the publication of the 1999 context document. Some of Reed and Metcalf's research questions are reframed in the context of the new data and several new research questions are presented.

\section{Chronology}

Reed and Metcalf presented no specific research questions or data gaps related to the chronology of the Gateway tradition, which they "tentatively dated between 400 B.C. and A.D. 1250, coterminous with corn horticulture in the area" (Reed and Metcalf 1999:131). Radiocarbon and ceramic data from excavated sites were summarized, with their attendant implications for Gateway tradition chronology (Reed and Metcalf 1999:Table 7-3). The authors noted that dates from Gateway tradition sites available at the time provided "tentative support" for an architectural progression proposed by McMahon (1997) that to be viable required a substantial span of time.

Important new data have been acquired and new interpretations regarding chronology offered since 1999. As noted previously, the Weimer Ranch sites yielded highly reliable AMS dates on maize that suggest an occupation that lasted no more than two centuries, and possibly less than a century. This, and the realization that regional data indicate a ca. 500-year-long hiatus in maize horticulture in west-central Colorado between A.D. 400 and 900 (with the exception of a single maize date [Stiger 2001:172]), caused Reed to redefine the temporal span of the Gateway tradition, reducing it from a 1650-year long in situ cultural development to a 200year long phenomenon lasting from approximately A.D. 900 to 1100 (Reed 2005). This represents a major reconceptualization of the Gateway tradition 
and calls into question whether the taxonomic concept of a tradition is an appropriate descriptor for the Gateway sites. A recent reliable date on bone collagen from site 5SM346, which yielded a calibrated age range of A.D. 990-1030 (Reed and Emslie 2008), further supports the conclusions derived from the Weimer Ranch maize dates. One implication of these data is that the in situ evolution of architecture proposed by McMahon (1997) is not tenable because the regional occupation was of insufficient duration to allow it.

Nevertheless, much work remains to be done on chronology. For example, it has been suggested that the one-to-two century duration of the Weimer Ranch occupation indicated by the radiocarbon data may be too long, and the actual occupation, based on the composition of the ceramic assemblage as reported by Lori Reed (2006), may have taken place during a 60-year period from A.D. 980-1040 (Varien 2007). This interpretation, of course, only takes one set of sites into account and further research is clearly needed. Superpositioning of architecture at Paradox I, where surface structures were built atop the remains of earlier pithouses, suggests that earlier occupations may be present in the region. Moreover, recent research by Bedingfield (2009) has revealed the regional presence of pottery types predating the Pueblo II period, suggesting either seasonal use of the region by early Puebloans or an earlier date of inception of the occupations subsumed under the Gateway tradition construct.

Origins, Cultural Affiliation, and Transitions

Hypotheses concerning the cultural identity of the people who constructed and inhabited the stone structures of the region have been proposed and debated since the 1920s. Reed and Metcalf (1999) rejected the hypothesis that they were Ancestral Puebloans, an interpretation favored by early investigators. The hypothesis that these sites represent a variant of the Fremont was examined in greater detail, because that idea carried greater weight at the time, having been advanced by several researchers since the 1970s such as Leach (1972), Toll (1977), Gleichman and Legard (1977), and especially McMahon (1997). Reed and Metcalf conceded that some sites in the region might represent isolated Fremont occupations, such as
Coombs Cave (42GR383), Roc Creek (5MN367), and one of the components at Paradox I (Reed and Metcalf 1999:136), but in general found little support for the Fremont hypothesis. Instead, they preferred to see the Gateway tradition as an indigenous development, influenced by contacts with Ancestral Puebloans and possibly San Rafael Fremont groups. Reed and Metcalf (1999:173-175) posed several specific research questions related to origins and cultural affiliation, including 1) examination of the utility of the Gateway tradition unit; 2) further consideration of the hypothesis of Ancestral Puebloan expansion outside the traditional Anasazi homeland, as reflected by the presence of Anasazi ceramics; and 3) additional study of whether the Gateway tradition represents an in situ development or immigration.

Two recent studies of ceramic assemblages from Late Prehistoric sites in the study area are relevant to these issues. Lori Reed's analysis of the Weimer Ranch pottery revealed that much of the assemblage represents Northern San Juan wares imported from the Mesa Verde and Dolores regions, but also that a slight majority appears to represent locally produced wares that "may be best described as emulation of Northern San Juan ceramics with local materials" (L.S. Reed 2006:34). Two important implications arise from this study. The first is that the great majority of imported wares at the Weimer Ranch sites were categorized as Northern San Juan (with one example of a Cibola tradition ware); no Fremont wares were identified. The second is that most of the pottery had likely been manufactured locally, and these wares resemble Northern San Juan ceramics to such an extent that it might be argued that the local potters were either from the Mesa Verde or Dolores areas or were trained by potters from those areas. The other important ceramic study is Bedingfield's (2009) analysis of sherds collected from 16 regional sites, which resulted in the identification of most of the analyzed specimens as Mesa Verde region wares. As with Lori Reed's study, no Fremont pottery was identified.

The close resemblance between Gateway and San Rafael Fremont architecture has been noted by several researchers, and has been advanced as evidence of a connection between these two traditions or even that Gateway sites in west-central Colorado sites should be considered Fremont 
(McMahon 1997; Toll 1977). While it may yet be demonstrated that Fremont ceramics are present at some sites such as Paradox I and Roc Creek (5MN367), thereby offer compelling evidence of Fremont occupation, to date no such clear evidence has been produced. Ceramics from the Paradox I site are in need of reanalysis by a ceramic specialist. Crane $(1977,1978)$ typed most of the pottery from the Roc Creek site as Emery Gray and Emery Corrugated (Fremont types), but the single sherd from this site analyzed by Bedingfield (2009) was typed as Moccasin Gray, a Northern San Juan ware. It has also been suggested that the ceramics from the Roc Creek site analyzed by Crane may be locally produced gray wares (Greubel et al. 2006:129). Unfortunately, the ceramics collected from the Roc Creek site by MSC were not included in the materials analyzed by Alpine and their current whereabouts is unknown.

The ceramic data described previously constitute evidence of a strong connection between Gateway tradition groups and Ancestral Puebloans to the south. The data certainly offer a compelling argument that at least some of the groups who occupied these sites were Ancestral Puebloans, an interpretation shared by at least one prominent Southwestern researcher (Varien 2007). Given the likely scenario of Ancestral Puebloan settlement of the area, the important research questions have begun to shift from the identity of these groups to the forces that drove their migration.

It is possible that the origins and cultural affiliations of Gateway tradition groups are not explainable as examples of Ancestral Puebloan settlement in every case. Greubel (2006) has suggested that Puebloan immigrants may have interacted symbiotically with indigenous huntergatherer groups, resulting in some of the observed patterns that appear non-normative when compared to Ancestral Puebloan architecture and material culture. A detailed consideration of this idea is beyond the scope of this article but should be regarded as an important question within the larger research domains of Gateway tradition cultural affiliation and social organization.

DNA analysis of the remains of individuals recovered from Gateway tradition sites has the potential to reveal possible genetic relationships with Ancestral Puebloans, Fremont peoples, or other contemporary groups (McMahon 1997; Reed and Metcalf 1999). Presently, human remains excavated from Paradox I and the Battleship site (5MN368) are extant and it may be feasible to pursuing DNA analyses on these individuals.

In view of the recently acquired data not available to Reed in 1997, it is appropriate to reexamine the usefulness and relevance of the Gateway tradition taxonomic construct. When Reed (1997) defined the new archaeological unit, he chose the unit concept "tradition" rather than alternative options such as period, phase, complex, or focus. Willey and Phillips (1958:37) defined tradition "as a (primarily) temporal continuity represented by persistent configurations in single technologies or other systems of related forms." They further noted that "the essential characteristic of all traditions is persistence in time" (Willey and Phillips (1958:63). In Volume 9 of the Encyclopedia of Prehistory is found the following definition: a tradition is "a group of populations sharing similar subsistence practices, technology, and forms of sociopolitical organization, which are spatially contiguous over a relatively large area and which endure temporally for a relatively long period" [italics added] (Peregrine and Ember 2002:2). In both of these definitions, the most significant characteristic of a tradition is its long temporal span.

Although Reed did not explicitly address why he chose to designate the Gateway as a tradition rather than using some other unit concept, it is clear that he regarded it as the equivalent-albeit on a much smaller geographic scale-of the longlasting cultural traditions of contemporaneous neighboring farming groups, the Ancestral Pueblo and Fremont. It made sense at the time; the Gateway tradition was thought to have come into being at approximately the same time as the Puebloan tradition, to have followed a similar trajectory of cultural development, and to have disappeared from the region at roughly the same time as both the Puebloan and Fremont traditions. However, new insights into the origin and duration of the Gateway tradition justify a reconsideration of the archaeological unit as defined by Reed in 1997. With respect to origins, it now appears likely that the inception of the Gateway reflects an influx of Puebloan settlers during the early Pueblo II period, rather than a separate and autonomous culture 
that developed in situ and eventually formed trade relationships with Puebloans to the south. Moreover, it is possible that Puebloan colonists interacted with local hunter-gatherer populations to the extent that the local groups may have adopted some of the material culture and subsistence practices of the newcomers. This may have resulted in hybridized adaptations that are archaeologically recognizable as Gateway sites, yet may differ in assemblage composition and in other ways from sites of Puebloan settlers. If this model has merit, it may indicate that the term Gateway encompasses a spectrum of technologies, subsistence practices, and modes of social organization. This runs somewhat counter to the concept of a tradition as "persistent configurations in single technologies," or a cohesive package of similar cultural traits and practices shared among a population. The other and more striking way that recent developments in Gateway research have altered Reed's original concept is that archaeologists now believe that this phenomenon persisted for only two centuries or even less, rather than for a millennium-and-a-half as Reed (1997) initially envisioned. This relatively brief span of time combined with the potential variability among Gateway sites undermine and appear to disqualify the Gateway phenomenon as a tradition.

There is another unit concept that fits the current understanding of Gateway more aptly: the phase. Willey and Phillips defined "phase" as "an archaeological unit possessing traits sufficiently characteristic to distinguish it from all other units similarly conceived, whether of the same or other cultures or civilizations, spatially limited to the order of magnitude of a locality or region and chronologically limited to a relatively brief interval of time" (Willey and Phillips 1958:22). The Gateway phenomenon, therefore, fits this unit concept because it is both spatially and chronologically limited. Roughly contemporaneous taxonomic analogs can be seen on the eastern side of the Rocky Mountains with the Apishapa and Sopris phases (Zier and Kalasz 1999).

\section{Settlement Patterns}

Reed and Metcalf (1999:136-137) discuss the settlement system model put forward by Crane (1977, 1978) and present a number of test implications that, if confirmed, would support the model. Recent data are relevant to at least two of the hypotheses posed for this research domain. The first pertains to the use of faunal remains as indicators for season of occupation: it is posited that they should reflect "all-season occupation of structural sites" (Reed and Metcalf 1999:137). The second states that "structural sites should be restricted to elevation zones where horticulture is possible," a proposition that was known to be untrue even in 1999, but upon which more recent data have shed additional light (Reed and Metcalf 1999:137).

With regard to the first question, analysis of the faunal remains from the Weimer Ranch sites (Greubel et al. 2006; Lubinski 2005) resulted in the identification of a number of bones from subjuvenile mammals that, in toto, indicate occupations occurring from spring into summer. As Reed (2007) notes, this does not necessarily indicate that the sites were not occupied at other times of the year. The substantial architecture and presence of storage features at some sites would seem to support cold-weather-and, therefore, probable yearround-occupation. Nevertheless, the question of year-round habitation of Gateway phase sites has not entirely been resolved and should continue to be considered an important research issue. For example, the possibility that the sites represent Ancestral Puebloan "summer houses" as suggested by Jeançon (1924), and potentially part of the settlement system of Ancestral Puebloan groups in the Dolores and Dove Creek areas should be more closely evaluated (Varien 2007).

To date, structural Gateway phase sites have been documented in a variety of topographic settings and at various elevations, from relatively low elevation sites near reliable water sources where maize horticulture would have been possible, to isolated structures in mid-elevation settings where horticulture was probably not feasible, to high elevation sites such as the Jeff Lick Stone Circles that seem to have functioned as residential bases for warm season hunting and gathering. Nonstructural sites yielding Ancestral Puebloan ceramics have also been found, but to date no serious effort to incorporate these sites into a comprehensive settlement model has been attempted.

The larger, lower elevation, sites such as Paradox I and the Weimer Ranch sites have yielded clear 
evidence of horticulture in the form of maize remains. The Jeff Lick Stone Circles site has recently yielded direct evidence of meat storage in the form of a positive protein residue result from a storage feature (Martin and Shelton 2015). Between the lower elevation sites and the Jeff Lick site, a number of structural sites extend up the flank of the Uncompahgre Plateau along tributaries of the San Miguel and Dolores rivers. Some of these sites, many of which are atop prominent ridges, were documented by Reed and Emslie (2008), who noted the possibility that they are inter-visible. This is an intriguing and potentially important possibility that requires further research. These sites may be part of a network of way stations - as suggested by Martin and Shelton (2015) for the Jeff Lick sitealong a series of trails or travel corridors connecting the lower elevation population centers with the high country. Moreover, there are several poorly known Gateway phase sites within the Escalante Creek drainage on the northeastern flank of the Uncompahgre Plateau that were investigated by the Huschers $(1939,1943)$, including the so-called Harvey Place Hogan (their site $\mathrm{HH}$ ), the Middle Fork (of the Escalante) Hogans (site HMF), and sites HSP, HBL, and HMH. From the Jeff Lick site, passing over the crest of the Uncompahgre Plateau into the Escalante Creek drainage system is relatively easy. It would appear that a Late Prehistoric network of sites once existed that extended from the largest Gateway phase habitations in the San Miguel basin and Paradox Valley, up to the crest of the Uncompahgre Plateau, and thence down into the lower Escalante Creek drainage. It might be posited that this travel corridor enabled an exchange network that moved resources back and forth between these areas and possibly to areas beyond.

\section{Subsistence}

The Northern Colorado River basin context document describes what was known in 1999 about Gateway subsistence, which was believed to have been a mixed regime of hunting, gathering of wild plant foods, and maize horticulture represented at habitation sites that were occupied during all seasons (Reed and Metcalf 1999). Recent data have not altered this characterization of Gateway subsistence, but some new data have refined or clarified current views on the economy of these groups. The specific questions and associated data gaps are focused on stable carbon isotope analysis of human skeletons, which would reveal reliance on maize as reflected by ratios of $\mathrm{C}_{4}$ to $\mathrm{C}_{3}$ plants; the presence of subsistence remains reflecting year-round habitation at structural sites; and the presence of large quantities of intensively processed faunal bone at long-term habitation sites (Reed and Metcalf 1999:138). Other questions posed by Reed and Metcalf (1999:174) include: 1) the relative importance of horticulture in the Gateway subsistence system; and 2) comparisons between the manner in which Formative-era horticulturists and non-horticulturalists exploited wild plants and animals.

The analysis of the Weimer Ranch materials resulted in major contributions to understanding Gateway subsistence. Maize remains, though not abundant, were fairly ubiquitous, occurring at five of the nine sites studied (Greubel et al. 2009). Usewear analyses of manos and metates suggested that many were used for grinding corn. Even more ubiquitous, however, was the evidence for intensive faunal procurement. Excavations at the Weimer Ranch sites yielded 280 projectile points (Greubel et al. 2006). There are some indications that more were once present in these assemblages, but were pilfered over the years as the collections resided in various poorly protected locales. Nearly 2,000 faunal bones from the sites reflect a robust hunting economy that included mule deer, elk, bison, bear, probably bighorn sheep, and a host of small mammals. The results of the faunal analysis from the Weimer Ranch sites generally echo those from Paradox I (Kasper 1977), and suggest that Gateway groups relied on hunting to a greater degree than Puebloan groups to the south, but less than regional Archaic and Ute peoples (Greubel et al. 2006; Reed 2007). Based on artiodactyl indices, the occupants of the Weimer Ranch sites relied on hunting slightly more than most Fremont groups (Greubel et al. 2006). DARG's recent research at the Jeff Lick Stone Circles site on the Uncompahgre Plateau (Martin and Shelton 2015) confirms the suspicions of earlier researchers that the site functioned as a base for seasonal hunting forays, and provides crucial evidence of the existence of nodes within the settlement system largely devoted to big-game hunting. 
With respect to the specific questions posed by Reed and Metcalf, Patrick Lubinski's (2005) analysis of the faunal remains from the Weimer Ranch sites-many of which are highly fragmentedis consistent with intensive processing of bone, which supports the idea of lengthy, possibly yearround occupations. No data are available for stable carbon isotope ratios obtained from human skeletal material, but human remains excavated from the Paradox I and Battleship sites might be subjected to such analyses. New data tend to confirm, rather than yield new insights into, previous ideas concerning the role of horticulture among Gateway phase groups. That is, the evidence suggests that maize was an important component of the diet of these groups, but almost certainly not to the extent that it was among Ancestral Puebloans to the south. It would appear, based on all current evidence, that Gateway phase groups exploited wild floral and faunal resources in ways similar to regional non-horticulturists, though likely somewhat less intensively, given their partial reliance on cultigens. One possible difference may have been a more intensive effort on the part of Gateway groups to procure surpluses of meat for possible exchange with Pueblo peoples to the south, although Reed (2007) found little archaeological evidence for this.

\section{Technology}

Reed and Metcalf (1999) summarize various aspects of Gateway technology, focusing primarily on architecture, but also briefly summarizing what was known at the time about projectile points, ceramics, and ground stone implements. Although no explicit research questions were offered for this topic, their discussion clearly revealed the data gaps. Variability in architecture is noted, encompassing pit structures, round and rectangular surface masonry structures, contiguous and non-contiguous rooms, and, rarely, unusual features such as enclosing walls. Representative Gateway phase structures are shown in figures 3 and 4 . For examples of the variability in architectural plans, see Greubel and others (2009), Hurst (1946), and Reed and Emslie (2008). The reasons for such variability are not known. A hypothesis advanced by McMahon (1997; see also Crane 1977) suggested diachronic change in architecture similar to that seen in the Southwest but occurring over a more compressed time span. Other aspects of architecture that were not well understood included the nature of interior features.

Gateway projectiles are described as small corner-notched points that likely tipped arrows. Pottery is characterized as being dominated by Pueblo II types that were likely imported from the Mesa Verde region between A.D. 900-1100, with no evidence for local manufacture. Ground stone implements at Gateway sites, based on evidence available in 1999, were regarded as non-distinctive and did not indicate heavy reliance on horticulture. Reed and Metcalf (1999:174-175) also identified the following important research issues: 1) additional data are needed on the range of variation in habitation structures at Formative-era sites in western Montrose and San Miguel counties; and 2) re-analysis of ceramic assemblages from western Montrose and San Miguel counties that have been classified as Fremont is needed.

No extensive excavations at Gateway phase sites have been undertaken since the 1999 context document was written; therefore, little new information concerning architecture has been generated. Nevertheless, documentation of 12 structural sites by Reed and Emslie (2008) has produced some new data regarding architecture and at least one other study has reconsidered the meaning of architectural variability at the Weimer Ranch site complex (Greubel 2006). The former project expands the database of well-documented structural sites in the region, resulting in baseline data that can be used to address the range of variability in Gateway phase architecture. The latter study presents a model of social organization that, in part, relies on assigning meaning to architectural variability. The most important aspects of this study are the inferences regarding possible integrative structures, communal spaces, and storage facilities at the sites. The identification of small, circular stone features at Paradox I, Cottonwood Pueblo, Weimer IV, and the Jeff Lick site as storage facilities has thus far been mostly speculative. However, DARG's recent work at the Jeff Lick site supports the interpretation of such features as storage units (Martin and Shelton 12015).

Numerous projectile points in the Weimer Ranch assemblages were analyzed by Alpine; examples from Paradox and the Weimer Ranch sites 


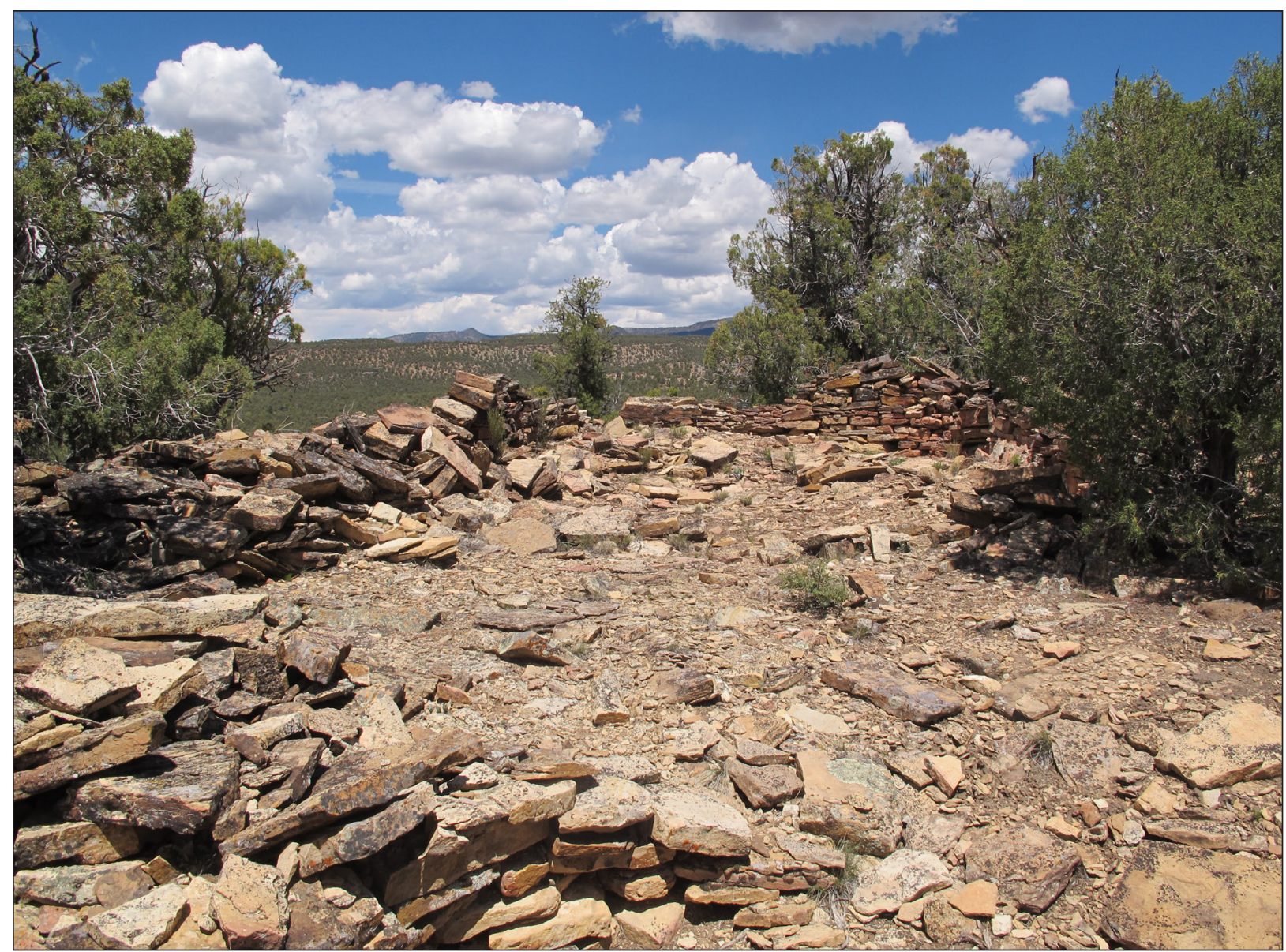

Figure 3. Tabeguache Pueblo, excavated by Hurst (1946). (Photo by Rand Greubel).

are shown in figure 5 . The majority are arrow points representing types that would not appear out of place at either a Fremont or a Pueblo II site (Rosegate or Pueblo II side-notched), though many closely resemble a unique type of arrow point recovered from Pueblo II sites in the Dolores area (Bradley 2000; Greubel et al. 2006:Figures 7-11). Ground stone assemblages from these sites are dominated by one-hand manos. Use-wear analyses of metates, however, suggest that most were used for grinding maize (Greubel et al. 2006:32), as was the single two-hand mano identified. Although not present in the materials analyzed by Alpine, a photograph of excavations at the Weimer IV site shows a grooved maul in situ. Grooved mauls are relatively common on Ancestral Puebloan sites but uncommon at sites north of the Northern San Juan region.

Many important questions about Gateway phase ceramics have been answered since the 1999 context document was published. The analyses of substantial ceramic assemblages collected from Gateway phase sites has demonstrated that many wares were probably manufactured in the Northern San Juan region (Bedingfield 2009; Greubel et al. 2006; L. Reed 2006, 2007). Even more significantly, Lori Reed's $(2006,2007)$ analysis of the Weimer Ranch ceramics revealed the likely existence of a previously unknown indigenous ceramic tradition that employed local materials to manufacture Northern San Juan-style pottery. Examples of both Northern San Juan and locally manufactured wares are shown in figure 5. As Bedingfield (2009:186) has noted, further research is needed to "verify the viability" of this local ceramic tradition. Nevertheless, Lori Reed's analysis marks a significant step forward in understanding the technology and influences associated with Gateway phase pottery. With respect to one of the questions posed in the 1999 context, no additional progress has been made in reanalyzing ceramic assemblages that have been 


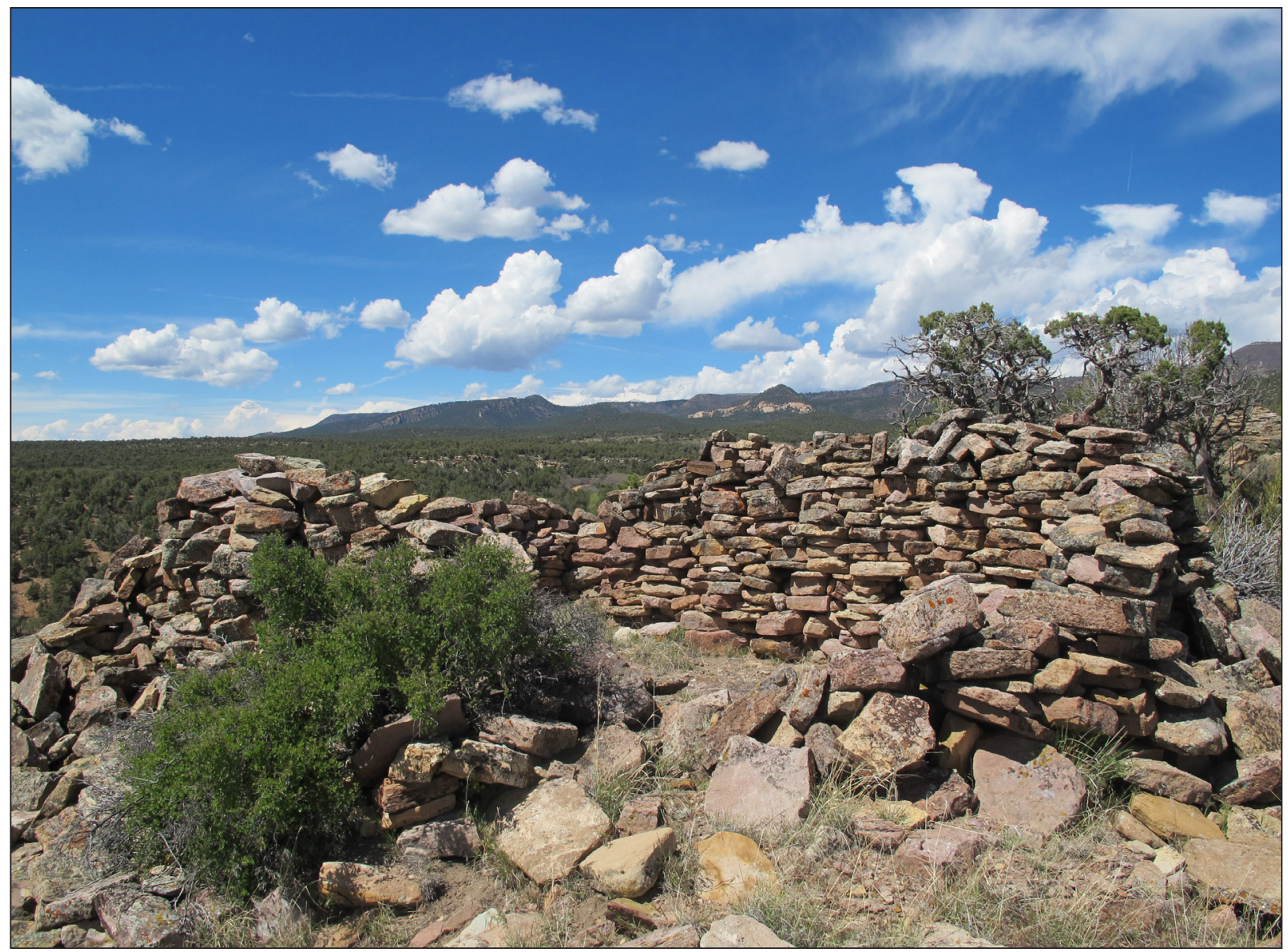

Figure 4. Site 5MN364, a single-room structure on a high promontory. (Photo by Rand Greubel).

previously identified as Fremont; this remains an important research concern.

\section{Social Organization}

In their discussion of social organization in the 1999 context document, Reed and Metcalf focus on Crane's (1977) model as presented in her M.A. thesis. Crane suggested that the sites characterized by non-contiguous circular structures reflected independent households comprising nuclear families, with little or no evidence for social integration. In contrast, the sites with rectangular structures containing contiguous rooms were thought to be a later development that arose as populations increased and greater inter-household cooperation became necessary. Reed and Metcalf (1999:139) propose four test implications for Crane's hypothesis:

1. Sites with contiguous rooms should date later than sites with individual rooms;

2. Separate, contemporaneous households as represented by non-contiguous structures will exhibit considerable redundancy in features and materials, indicating household autonomy;

3. Some of the rooms at contiguous-structure sites should exhibit specialized functions;

4. Larger populations should be in evidence at sites with contiguous rooms.

Reed and Metcalf discussed the evidence available in 1999 for each of these propositions. They concluded that the chronology of architecture was not well enough known to address the first issue. The second proposition was considered credible but insufficient data were available to address it further. The third test implication seemed to have limited support based on data obtained by Hurst (1948a) during his excavations at Cottonwood Pueblo, but aside from this one example, not enough was known about room functions within 
contiguous-room structures. With respect to the fourth issue, ethnographic data pertaining to the relationship between roofed area of domiciles and population size were employed to estimate the populations of several excavated Gateway sites representing both contiguous and non-contiguous rooms. This exercise did not reveal any clear patterns demonstrating that larger populations were associated with sites exhibiting contiguous rooms. Reed and Metcalf concluded that the social organization of all Formative-era traditions in the region merits further study.

Data obtained, or research conducted, since the 1999 context document was published has remedied some of these data gaps. In particular, AMS dating of maize remains at the Weimer Ranch sites has demonstrated the likelihood that most, if not all, of the sites were occupied contemporaneously (Greubel et al. 2006, 2009), which is not consistent with the first proposition. On the other hand, research at these sites tends to confirm the second and third propositions, at least to a degree. The fourth proposition has, to date, not been clearly demonstrated.

Greubel's (2006) modeling of the social organization of the Weimer Ranch sites concluded that the sites represent a community (sensu Varien 1999), a seemingly logical conclusion given their contemporaneity and close physical proximity on the landscape. This interpretation is essentially at odds with Crane's $(1977,1978)$ ideas about social organization, especially those that invoke diachronic change. Any model of social organization of Gateway phase groups, however, must take into account the striking diversity of domestic architecture, the presence of possible integrative structures and spaces, and the meanings of the variability between apparently coeval sites and assemblages. One possible element in all this variability is a hypothetical interdependent relationship between Puebloan immigrants and indigenous hunter-gatherers, who may have become part-time horticulturists themselves. The presence of what may have amounted to multiple interacting ethnic groups in the region may explain some of the diversity apparent among the sites and is potentially a critical aspect for understanding the social organization of these groups. The possibility of diversity among Gateway phase groups in terms of origins, subsistence and settlement systems, and social organization mirrors similar insights in Fremont studies (Madsen and Simms 1998) and suggests new research directions.

\section{Extra-Regional Relationships}

In the 1999 Northern Colorado River basin prehistoric context, it is noted that, based on the ceramic evidence, Gateway people "maintained trading relations with the Anasazi, especially during the Pueblo II period" (Reed and Metcalf 1999:140). Reed and Metcalf also suggested the possibility that Gateway phase groups interacted with Fremont groups, based on architectural styles and limited ceramic evidence. Based on new ceramic data, the posited relationships with Ancestral Puebloans are well supported by the evidence. In contrast, no new compelling evidence for interaction with Fremont groups has come to light over the past 18 years. However, the ceramic assemblages that ostensibly contain Fremont pottery types, including from the Roc Creek site and from some of the structures at Paradox I, need to be re-analyzed and may yet reveal the presence of Fremont ceramics, which may indicate either extra-regional relationships with Fremont groups or bona fide Fremont occupations. As such, subjecting these assemblages to new analyses by expert ceramic specialists should be considered an important research goal. The ceramics recovered by Leach and his students in 1970 at Paradox I are housed at San Diego State University. Unfortunately, the locations of the Roc Creek site ceramics and the artifacts recovered by MSC at Paradox I in 1973 are unknown.

\section{Conclusions and Suggestions for Future Research}

This article has focused on brief descriptions of recent research into the Gateway tradition (now reformulated as the Gateway phase), summaries of the research questions and data gaps identified by Reed and Metcalf (1999), and the ways in which recent data have answered those questions and filled the data gaps. In addition to many questions originally asked by the authors of the 1999 context document that remain unanswered, some new areas of research can be suggested. 


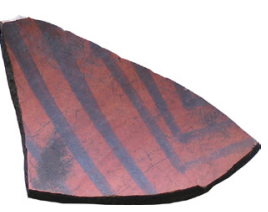

a.

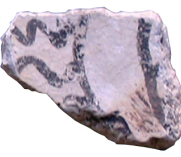

f.
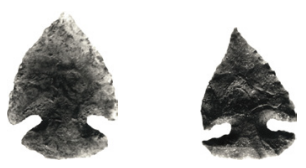

1.

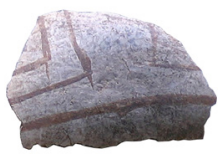

g.

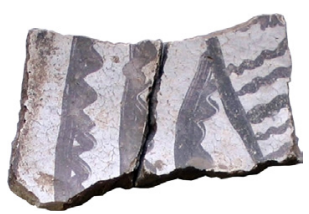

b.

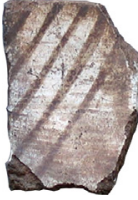

h.

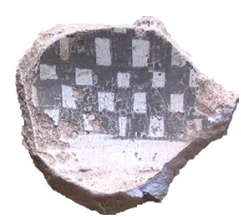

c.

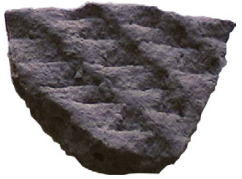

i.

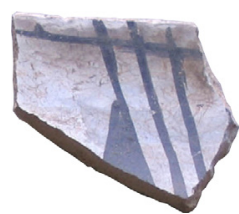

d.

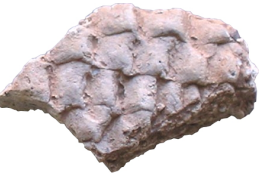

j.

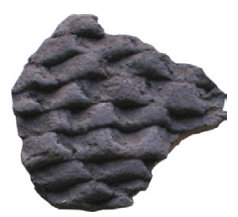

e.

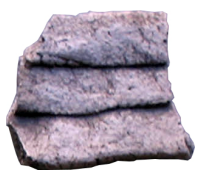

$\mathrm{k}$.

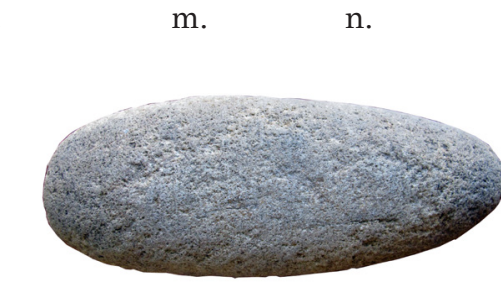

t.

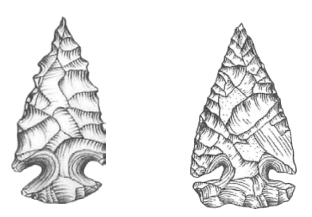

0.

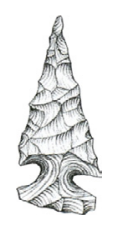

p.

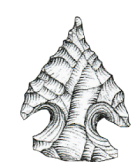

q.

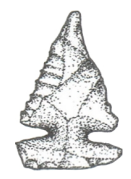

r.

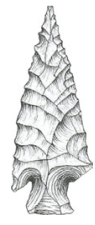

S.

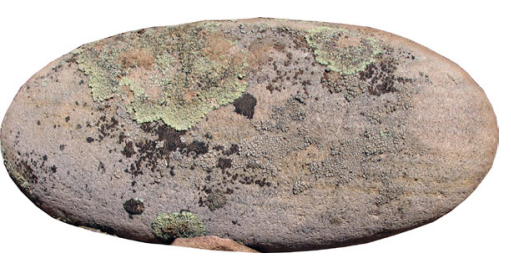

u.

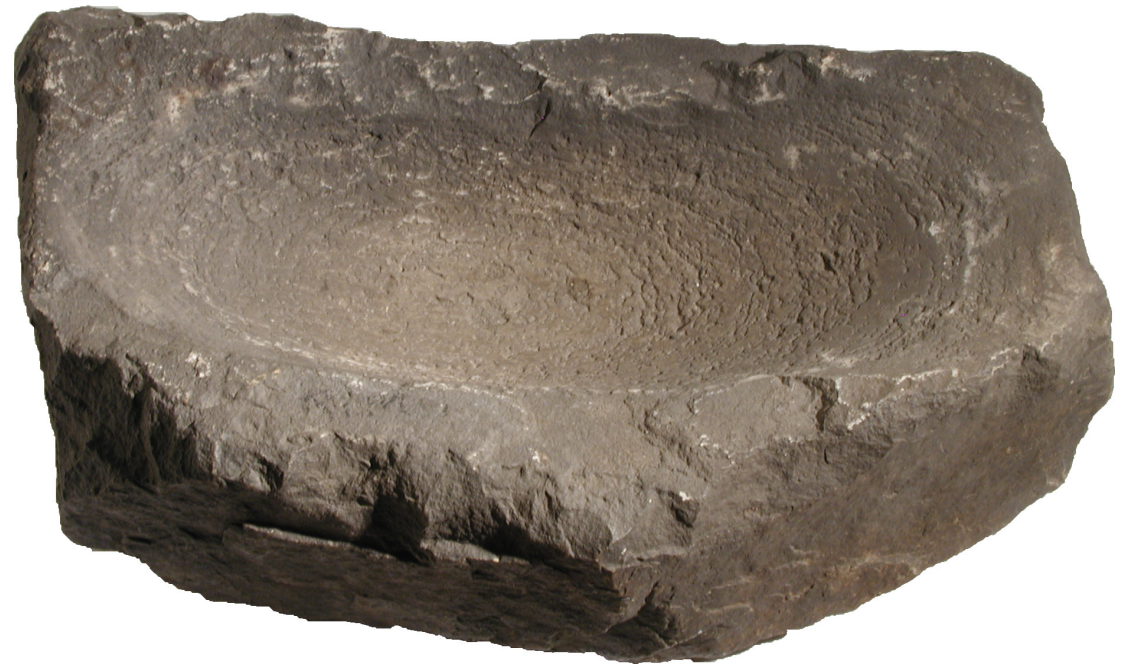

v.

Figure 5. Representative Gateway phase artifacts. a-e, Northern San Juan wares from the Weimer Ranch sites; $f-k$, locally manufactured wares from the Weimer Ranch sites; $l-m$, arrow points from Paradox (5MN191); $n$-s, arrow points from the Weimer Ranch sites; $t$, two-hand mano from Paradox (5MN191); $u$, two-hand mano from the Weimer Ranch (Battleship, 5MN368); and v, metate from the Weimer Ranch (Cottonwood Pueblo, 5MN654). Artifacts are not to scale. 
Although the understanding of Gateway phase settlement patterns has improved, more inventorylevel data are needed to better address this important research issue. Archaeologists need to achieve a better understanding of the relationships between particular site types and their settings and how each site type functioned within the settlement system. The possibility that Gateway phase groups were engaged in collecting surpluses of meat for exchange with Puebloan groups to the south, though presently only weakly supported by the archaeological evidence, is an important research question because it articulates with several research domains, including settlement patterns, subsistence, and extra-regional relationships. It is also possible that other resources were traded with more southerly Ancestral Puebloans, such as medicinal and food products derived from wild plants that were more abundant in upland environments. The examination of such questions might lead to new insights regarding the origins of the Gateway phase.

Linked to the concerns noted previously is the question of the geographic extent of the Gateway phase. Figure 1 displays the approximate extent of Gateway sites as conceived by Reed (1997:Figure 1), with a much smaller, roughly triangular area that might be described as the better-defined core area of the Gateway phase. This core area encompasses most of the major known Gateway phase structural sites such as Paradox I, the Weimer Ranch sites, the Maze, Rim Rock Ruin, and Tabeguache Pueblo (figure 2). With regard to the much larger area defined by Reed, more research needs to be conducted to determine whether sites consistent with Gateway phase occupations are present throughout this region. A short distance to the northwest of the Gateway core area is the eastern edge of the Fremont culture area. Directly to the west of the Gateway core area, Reed's (1997) original definition of the Gateway tradition also included an area roughly defined by a six-sided polygon with the modern communities of Gateway, Dewey, Moab, Hatch Point, Monticello, and Egnar as its corners. However, in the twenty years since, no serious effort to integrate structural sites and sites with Puebloan ceramics in this more westerly region into the Gateway construct has been attempted. Therefore, the inclusion of such sites in the Gateway phase must be regarded as hypothetical and a topic for future research.
Ancestral Puebloan ceramics are very sparsely present in other areas of west-central Colorado north of the Gateway core area, but contemporaneous groups are thought to have lived an essentially hunting-and-gathering lifestyle that did not include horticulture, ceramic manufacture, or seasonal sedentism. Reed (2005; Reed and Metcalf 1999) has termed this adaptation the Aspen tradition. To the south, there is a substantial gap between the southernmost known sites within the Gateway core area and the northernmost Ancestral Puebloan settlements, as shown in figure 1 . This in-between region-which encompasses the Dry Creek basin, Big and Little Gypsum valleys, the Disappointment Valley, and the middle reaches of the Dolores River between Dove Creek and Bedrock (figure 2)-is not well understood archaeologically. For example, Ancestral Puebloan ceramics are not uncommon on sites in this region and Formative-era arrow points are relatively ubiquitous, but it is not clear if these artifacts are associated with Gateway phase peoples, with seasonal, logistical use of the area by Puebloans, or with use of the area by both groups. Additional research at sites in this in-between region might result in a greater understanding of the settlement and subsistence systems practiced by the groups that used it. This may help to reveal their identities and interrelationships.

The denouement of the Gateway phase is poorly understood. It is possible that these groups migrated south in the eleventh or early twelfth century to live among Ancestral Puebloan peoples. Alternatively, they may have remained in the region, but abandoned horticulture and its attendant semisedentary lifestyle and adopted a fully hunting-and-gathering lifeway. Such questions can only be answered by additional excavated data and continued research into artifactual and possibly genetic signatures that might be traced across the landscape.

The possibility that some Gateway phase sites functioned as way stations along important travel corridors and may have been inter-visible to allow communication across great distances are important concepts that require additional research. Such research would be amenable to viewshed studies and other geospatial analyses. The defensive nature of some Gateway phase sites, which was remarked upon almost as frequently by early researchers as by 
local ranchers with their stories of "Indian forts", is a legitimate research issue. It is difficult to explain the isolated and even precipitous settings of some sites, and their massive walls, without invoking some sort of defensive function. Nevertheless, alternative explanations such as their possible use as game observation stations should be considered.

Most research into Gateway phase rock art has been ad hoc or peripheral to other research goals. Gateway rock art clearly deserves much more attention and explicit comparative analyses with other regional styles, because it may hold the potential for revealing information about the origins and cultural relationships of these groups matched only by ceramic studies. Such work might begin with a comprehensive survey (comprising literature searches and new fieldwork) of all Formative-era rock art in the region encompassed by known Gateway phase habitation sites, followed by rigorous comparative analyses of styles, elements, motifs, and compositions.

Much has been learned about Gateway phase ceramics over the past 18 years, but much more can be learned. Ceramic assemblages that have not been analyzed for many decades - and never by an expert ceramic analyst - are extant and could be subjected to typological and technological studies and to modern characterization techniques such as INAA. New assemblages can also be obtained through data recovery at some of the many sites in the region that retain intact deposits.

In addition to the research issues and data deficits identified in the previous sections, archaeologists simply need to have more data from controlled excavations using exacting modern field methods. It is a sad reality that many of the best structural sites in the region were excavated many decades ago using coarse methods, or were poorly excavated out of existence by well-meaning but careless investigators, or have suffered the depredations of looters to the extent that they retain little useful data. Moreover, even the sites that were excavated with tolerably serviceable methods usually had little or no subsequent reporting. Nonetheless, some sites still retain intact archaeological deposits that have the potential to contribute a great deal of additional information about the Gateway phase. Sites, or areas of sites, that are known or suspected to contain valuable archaeological deposits include:
- The plaza area within the enclosing wall at Cottonwood Pueblo;

- The midden below the canyon rim at Cottonwood Pueblo;

- The structure called Pinyon House at Cottonwood Pueblo;

- Storage features at Cottonwood Pueblo and the Weimer IV site;

- The structure called Edge House at the Weimer IV site;

- Extramural areas at the Weimer IV site;

- $\quad$ A possible structure at the Battleship site;

- Structures at or near the Last Hill site (5MN518), including a possible pithouse;

- Unexcavated structures, features, and extramural areas at the Jeff Lick Stone Circles site;

- Several sites recorded by Reed and Emslie (2008), but especially 5MN8429, 5MN8430, and 5MN1224;

- Some areas at Paradox I, although the extent of intact deposits is unknown;

- Other structural sites in western Paradox Valley reported by Woodbury and Woodbury (1932), only a few of which have been formally recorded and none of which have been professionally excavated; and

- Un-vandalized portions of site 5SM346 (the Maze).

Finally, considerable new data might be derived from analyzing or reanalyzing excavated Gateway phase assemblages, in addition to ceramics as noted previously, that are curated at various locations. Two important collections include those recovered from Paradox I by Leach, which is currently curated at San Diego State University in San Diego, California, and the materials excavated by Hurst from Tabeguache Pueblo and Lone Tree House (House 4) at Cottonwood Pueblo, which is curated at Western State Colorado University in Gunnison, Colorado. New research into existing collections, combined with new fieldwork, will certainly further advance knowledge of the Gateway phase and possibly answer many of the puzzling questions that remain.

Acknowledgements. I would like to thank Dr. Mark D. Mitchell, Dr. Mark D. Varien, and an anonymous reviewer, who reviewed an earlier version of this paper. Their comments have resulted in a much-improved article. Aaron M. Goldman 
made figures 1 and 2 and Connor C. Johnen prepared figure 5. I am grateful to both for their excellent work. Curtis Martin and Holly Shelton of DARG gave me a copy of their intriguing report of excavations at the Jeff Lick site; I thank them for their willingness to share data. I also wish to acknowledge the following individuals: the late Alexandra Vondracek, who provided information on MSC's excavations at Paradox; Lori S. Reed, who performed such important work on the Weimer Ranch ceramic assemblages; Alan D. Reed, who gave me the opportunity to work with the Weimer Ranch materials; Michael J. Prouty, who worked with the Paradox materials at San Diego State University and gave me much appreciated updates on the status of that collection; and Todd C. McMahon, who kindly provided me with important literature and whose admirable work concerning the Late Prehistoric structural sites of west-central Colorado has contributed a great deal to our understanding of this period of prehistory. I am grateful to Alpine for allowing me the time and resources to write this article, and to Bill Harris and the Chipeta Chapter of the Colorado Archaeological Society, who facilitated my interest in Gateway phase sites by conveniently organizing field trips to the west end of Montrose County. Finally, a sincere thank you to my friend and colleague Dr. Bradford W. Andrews, whose insightful research into the Gateway phenomenon, combined with our many thought-provoking conversations, have been of key importance in developing many of the ideas described in this article.

\section{References Cited}

Andrews, Bradford W.

2006 Expanding our Perspective on the Gateway Tradition: New Information from the Weimer Ranch Collection. Paper presented at the Great Basin Anthropological Conference, Las Vegas, Nevada.

Andrews, Bradford W., and Rand A. Greubel

2007 The Gateway Phenomenon: A Punctuated Formative Development Linked to Inter-Regional Population Dynamics? Paper presented at the 72nd Annual Meeting of the Society of American Archaeology, Austin, Texas.

Bedingfield, Kenneth Brian

2009 Formative-Era Exchange, Interaction, and Social Organization in West-Central Colorado: A Ceramic Study Utilizing Instrument Neutron Activation Analysis. Unpublished Master's thesis, Department of Anthropology, University of Colorado, Denver.

Bradley, Bruce

2000 Points From Two Pueblo Sites in Southwestern Colorado. Electronic document, http://www.primtech. net/chips/Points.htm.

Crane, Cathy J.

1977 A Comparison of Archaeological Sites on the Uncompahgre Plateau and Adjacent Areas. Unpublished Master's thesis, Department of Anthropology, Eastern New Mexico University, Portales.

1978 Cultural Adaptation Along the Tributaries of the San Miguel River, West Central Colorado. Southwestern Lore 44(4):1-10.
Currit, Richard L.

1992 Cultural Resource Inventory of the North Love Mesa, Motherlode, Socks, and Dan Timber Sale, Ouray Ranger District Uncompahgre National Forest, Montrose and Mesa Counties, Colorado. Prepared for Grand Mesa, Uncompahgre and Gunnison National Forests, Delta, Colorado.

Gleichman, Peter J., and Carol L. Legard

1977 Cultural Resource Inventory of the San Miguel Resource Area, Western Colorado, Montrose and San Miguel Counties. Prepared by Mesa Verde Research Center.

Gleichman, Peter J., Susan Eininger, and Douglas D. Scott

1982 The Archaeology of the West End (San Miguel

Resource Area). In Archaeological Resources in

Southwestern Colorado, edited by Susan Eininger, Peter

J. Gleichman, Deborah A. Hull, Paul R. Nickens, Allen

D. Reed, and Douglas D. Scott, pp. 428-523. Cultural

Resources Series 13. Bureau of Land Management,

Denver, Colorado.

Greubel, Rand A.

2006 Society and Use of Space at the Weimer Ranch Site Complex. Unpublished Master's thesis, University of Leicester, England.

Greubel, Rand, Bradford Andrews, Rosemary Sucec, Michael Brown, Elizabeth Amos, Richard Currit, John Wenaas, and Dulaney Barclay

1989 Colorado Cultural Resource Inventory Site Form for the Jeff Lick Stone Circles Site (5MN3462).

History Colorado, Office of Archaeology and Historic Preservation, Denver, Colorado.

Greubel, Rand A., Bradford W. Andrews, and Alan D. Reed

2006 The Weimer Ranch Sites Revisited: Analysis of

Materials From a Prehistoric Farming Community in West

Central Colorado. Alpine Archaeological Consultants,

Inc., Montrose, Colorado. Prepared for Uncompahgre/

Com. Inc., Delta, Colorado. Submitted to Bureau of Land

Management, Southwest Center, Montrose, Colorado.

Greubel, Rand A., Alan D. Reed, and Bradford W. Andrews

2009 Gaining Ground on the Gateway Tradition: Analysis of Materials from Weimer Ranch, a Prehistoric Farming Settlement in West-Central Colorado. Colorado Archaeology 75(1\&2):30-61.

Hurst, Clarence T.

1946 The 1945 Tabeguache Expedition. Southwestern Lore 12(1):7-15.

1948a The Cottonwood Expedition, 1947 - A Cave and a Pueblo Site. Southwestern Lore 14(1):4-19.

1948b Cottonwood Cave and Hill Pueblo 1948. Draft of Official Report to Department of Agriculture, Smithsonian Institution, and the American Philosophical Society. Unpublished ms. on file at Western State Colorado University, Gunnison, Colorado.

Huscher, Betty Holmes, and Harold A. Huscher

1939 Field Notes for 1939. Unpublished ms. on file at Bureau of Land Management, Montrose, Colorado.

1943 The Hogan Builders of Colorado. Southwestern Lore 9(2):1-92.

Jeancon, Jean Allard

1924 Archaeological and Ethnologial Research During 


\section{Greubel}

the Year 1924. Unpublished ms. on file in the Jeancon Manuscript Collection, History Colorado, Denver.

Kasper, Jan C.

1977 Animal Resource Utilization at the Colorado Paradox Valley Site. Southwestern Lore 43(1):1-17.

Leach, Larry L.

1972 Fremont Settlement and Resource Utilization Patterns in Paradox Valley, Colorado. Unpublished research proposal submitted to the National Science Foundation, Washington, D. C.

Lubinski, Patrick M.

2005 Faunal Remains and Faunal Artifacts from Weimer Ranch in Southwestern Colorado. In The Weimer Ranch Sites Revisited: Analysis of Materials from a Prehistoric Farming Community in West Central Colorado, by Rand A. Greubel, Bradford W. Andrews, and Alan D. Reed, pp. C1-C37. Alpine Archaeological Consultants, Inc., Montrose, Colorado. Prepared for Uncompahgre/Com. Inc., Delta, Colorado. Submitted to Bureau of Land Management, Southwest Center, Montrose, Colorado.

Madsen, David B., and Steven R. Simms

1998 The Fremont Complex: A Behavioral Perspective. Journal of World Prehistory 12(3):255-336.

Martin, Chris A., and Holly Shelton

2015 Site Reevaluation and Test Excavations at $5 M N 3462$, the Jeff Lick Stone Circles, for the Grand Mesa, Uncompahgre, and Gunnison National Forest, in Montrose County, Colorado. DARG Project 2014-1. Dominquez Archaeological Research Group, Inc., Grand Junction, Colorado.

McMahon, Todd C.

1997 Official Recording of George and Edna Woodbury's

1931 Paradox Valley Survey and Considerations for

Reinterpretation. Unpublished ms. on file at History Colorado, Office of Archaeology and Historic Preservation, Denver, Colorado.

2000 Paradox Valley, Colorado: Cultural Interactions and Considerations for Reinterpretation. Southwestern Lore 66(3):1-29.

2004 By Any Other Name, the Fremont Culture of Colorado. Paper presented at the 77th Annual Pecos Conference, Bluff, Utah.

2007 West Central Colorado Formative-Piecing the Inter-Connected Culture Puzzle Together. Paper presented at the 72nd Annual Society for American Archaeology Conference, Austin, Texas.

McMahon, Todd C., and Ken Bedingfield

2001 Reconnaissance Survey of Sites Near Paradox Valley, Montrose County, Colorado. History Colorado, Office of Archaeology and Historic Preservation. Submitted to Bureau of Land Management, Montrose, Colorado.

Peregrine, Peter N., and Melvin Ember

2002 Encyclopedia of Prehistory, Volume 9: Cumulative

Index. Human Relations Area Files, Yale University.

Kluwer Academic/Plenum Publishers, New York.

Reed, Alan D.

1997 The Gateway Tradition: A Formative Stage Culture

Unit for East-Central Utah and West-Central Colorado. Southwestern Lore 63(2):19-26.

2005 Settlement and Subsistence During the Formative
Recent Developments in Gateway Phase Research

Era in West-Central Colorado. Colorado Archaeology 71(4):17-34.

2007 Patterns of Faunal Exploitation Evident at Horticultural Sites in West-Central Colorado. Paper presented at the 72nd Annual Meeting of the Society of American Archaeology, Austin, Texas.

Reed, Alan D., and Michael D. Metcalf

1999 Colorado Prehistory: A Context for the Northern Colorado River Basin. Colorado Council of Professional Archaeologists, Denver.

Reed, Alan D., and Steven D. Emslie

2008 Archaeological Assessment of Twelve GatewayTradition Sites in Western Montrose and San Miguel Counties, Colorado. Alpine Archaeological Consultants, Inc., Montrose, Colorado and University of North Carolina Wilmington. Submitted to Colorado Archaeological Society, Chipeta Chapter, Montrose, Colorado.

Reed, Lori Stephens

2006 Appendix A: Ceramic Artifacts. In The Weimer Ranch Sites Revisited: Analysis of Materials from a Prehistoric Farming Community in West Central Colorado, by Rand A. Greubel, Bradford W. Andrews, and Alan D. Reed. Alpine Archaeological Consultants, Inc., Montrose, Colorado. Prepared for Uncompahgre/ Com. Inc., Delta, Colorado. Submitted to Bureau of Land Management, Southwest Center, Montrose, Colorado.

2007 Exploring Ceramic Production at the Weimer Ranch Sites: Northern San Juan or Fremont Technological Signatures. Paper presented at the 72nd Annual Meeting of the Society of American Archaeology, Austin, Texas.

Schroeder, Albert H.

1964 The Cultural Position of Hurst's Tabeguache Caves and Pueblo Sites. Southwestern Lore 29(4):77-79.

Shott, Michael J.

1992 Radiocarbon Dating as a Probabilistic Technique: The Childers Site and Late Woodland Occupation in the Ohio Valley. American Antiquity 57(2):202-230.

Smiley, Francis E.

1985 The Chronometrics of Early Agricultural Sites in the Northern Southwest: Approaches to the Interpretation of Radiocarbon Dates. Unpublished Ph.D dissertation, Department of Anthropology, University of Michigan, Ann Arbor.

Stiger, Mark A.

2001 Hunter-Gatherer Archaeology of the Colorado High County. University Press of Colorado, Boulder.

Stiger, Mark A., and Mark Larson

1992 A Radiocarbon Date from the Cottonwood Cave Corn Cache and Problems Interpreting the Origins of Farming in Western Colorado. Southwestern Lore 58(2):26-36

Toll, Henry W. III

1977 Dolores River Archaeology: Canyon Adaptations as Seen Through Survey. Cultural Resource Series 4. Bureau of Land Management, Denver, Colorado.

Varien, Mark D.

1999 Sedentism and Mobility in a Social Landscape: Mesa Verde and Beyond. University of Arizona Press, Tucson. 
2007 Weimer Ranch Discussant Comments. Paper presented at the Society for American Archaeology, 72nd Annual Meeting, Austin, Texas.

Willey, Gordon R., and Philip Phillips

1958 Method and Theory in American Archaeology. University of Chicago Press.

Woodbury, George, and Edna Woodbury

1932 The Archaeological Survey of Paradox Valley and Adjacent Country in Western Montrose County, Colorado, 1931. The Colorado Magazine 9(1):1-21.

Zier, Christian J., and Stephen M. Kalasz

1999 Colorado Prehistory: A Context for the Arkansas River Basin. Colorado Council of Professional Archaeologists, Denver.

\section{Contributor Notes}

Rand A. Greubel grew up in western Colorado, where he developed an early interest in the archaeology of the Uncompahgre Plateau. He has a B.A. from the University of Colorado, Boulder, and an M.A. from the University of Leicester, U.K. His research interests include the Late Prehistoric period in west-central Colorado, forager-farmer interactions in prehistory, Ute archaeology, lithic technology, and spatial patterning on hunter-gatherer sites. $\mathrm{He}$ is a Principal Investigator and co-owner of Alpine Archeological Consultants, Inc., where he has worked since 1989. 